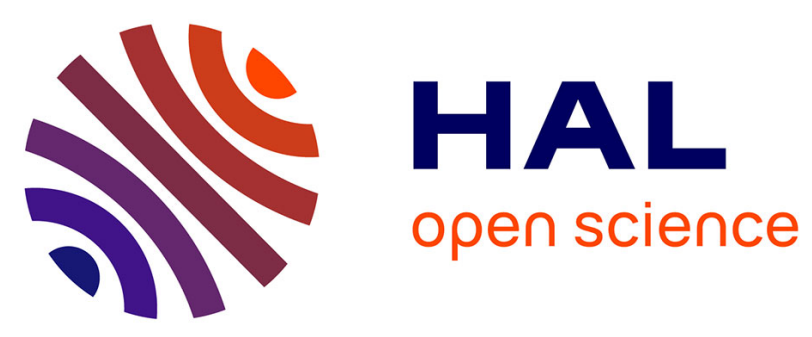

\title{
A New Regulation of IL-6 Production in Adult Cardiomyocytes by $\beta$-Adrenergic and IL-1 $\beta$ Receptors and Induction of Cellular Hypertrophy by IL-6 Trans-Signalling
}

Nicolas Szabo-Fresnais, Florence Lefebvre, Aurore Germain, Martine Pomérance, Rodolphe Fischmeister

\section{To cite this version:}

Nicolas Szabo-Fresnais, Florence Lefebvre, Aurore Germain, Martine Pomérance, Rodolphe Fischmeister. A New Regulation of IL-6 Production in Adult Cardiomyocytes by $\beta$-Adrenergic and IL- $1 \beta$ Receptors and Induction of Cellular Hypertrophy by IL-6 Trans-Signalling. Cellular Signalling, 2010, 22 (7), pp.1143-1152. 10.1016/j.cellsig.2010.03.009 . hal-02940454

\author{
HAL Id: hal-02940454 \\ https://hal.science/hal-02940454
}

Submitted on 16 Sep 2020

HAL is a multi-disciplinary open access archive for the deposit and dissemination of scientific research documents, whether they are published or not. The documents may come from teaching and research institutions in France or abroad, or from public or private research centers.
L'archive ouverte pluridisciplinaire HAL, est destinée au dépôt et à la diffusion de documents scientifiques de niveau recherche, publiés ou non, émanant des établissements d'enseignement et de recherche français ou étrangers, des laboratoires publics ou privés. 


\title{
A New Regulation of IL-6 Production in Adult Cardiomyocytes by $\beta$-Adrenergic and IL-1ß Receptors and Induction of Cellular Hypertrophy by IL-6 Trans-Signalling
}

\author{
Nicolas Szabo-Fresnais ${ }^{a, b}$, Florence Lefebvre ${ }^{a, b}$, Aurore Germain ${ }^{a, b}$, \\ Rodolphe Fischmeister $^{\mathrm{a}, \mathrm{b}}$, Martine Pomérance ${ }^{\mathrm{a}, \mathrm{b}}$
}

aINSERM UMR-S 769, F-92296, Châtenay-Malabry, France

${ }^{b}$ Univ Paris-Sud 11, IFR141, Faculté de Pharmacie, F-92296, Châtenay-Malabry, France

Correspondence to:

Rodolphe FISCHMEISTER

INSERM UMR-S 769

Faculté de Pharmacie

5, Rue J.-B. Clément

F-92296 Châtenay-Malabry Cedex

France

Tel. +33-1-46 835757

Fax +33-1-46 835475

rodolphe.fischmeister@inserm.fr 


\section{ABSTRACT}

The sympathetic nervous system and pro-inflammatory cytokines play key roles in numerous cardiovascular disorders. Chronic $\beta$-adrenergic receptor ( $\beta$-AR) stimulation in myocardium induces expression of pro-inflammatory cytokines, such as interleukin-1 (IL-1) and interleukin-6 (IL-6), which contribute to cardiac hypertrophy and failure. To evaluate the relationship between $\beta$-AR stimulation and pro-inflammatory cytokines, we studied the effects of the $\beta$-AR agonist isoprenaline (ISO) on IL-1-induced IL-6 production in adult rat ventricular myocytes (ARVMs). We report that ISO and IL-1 synergistically enhanced IL-6 gene expression and secretion. The synergistic effect of ISO was mimicked by cAMP elevating agents and involved the $\mathrm{G}_{\text {s }}$ protein/cAMP/PKA signalling pathway, but not the exchange factor EPAC. To evaluate the contribution of IL-6 to cellular hypertrophy, we examined the signalling pathways stimulated by the membrane-bound IL-6 receptor (IL-6R), and the IL-6 soluble receptor (sIL-6R) involved in the mechanism named IL-6 trans-signalling. The IL-6/sIL-6R complex promoted a rapid and persistent phosphorylation of STAT3 ${ }^{\mathrm{Tyr} 705}$ in ARVMs. Moreover, IL-6 trans-signalling increased protein synthesis, c-fos gene expression and B-type natriuretic peptide secretion, three markers of cardiac hypertrophy. IL-6 trans-signalling also increased cell size. In contrast, IL-6 alone had no significant effect on either cell size or STAT3 phosphorylation although it induced phosphorylation of ERK1/2, AKT and S6K, demonstrating the presence of a functional IL-6R in ARVMs. Taken together, these results demonstrate that $\beta$-AR stimulation synergises with IL-1 for IL-6 secretion in adult ventricular myocytes and indicate that IL-6 induces cardiac hypertrophy only via IL-6 trans-signalling. The IL-6 soluble receptor may thus serve as a switch for IL-6 to activate STAT3 phosphorylation and hypertrophy. 
Key Words:

$\beta$-adrenergic receptors

cAMP

IL-6

IL-1

STAT3

cardiac hypertrophy 


\section{Introduction}

Whereas an acute activation of the adrenergic nervous system stimulates cardiac function and participates in the "fight-or-flight" response, a chronic activation induces a pathological remodelling of the heart, which plays a crucial role in the pathogenesis of heart failure. Part of this process may involve pro-inflammatory cytokines. Indeed, chronic $\beta$-adrenergic receptor ( $\beta$-AR) stimulation induces cardiac expression of proinflammatory cytokines, such as tumor necrosis factor- $\alpha$ (TNF $\alpha$ ), interleukin-1 $\beta$ (IL-1) and interleukin 6 (IL-6) [1,2]. Moreover, myocardial dysfunction is associated with increased levels of all three cytokines [3-5] and elevated plasma levels of IL-6 and $\mathrm{TNF} \alpha$ have been found to be associated with increased risk of congestive heart failure in patients without prior myocardial infarction [6].

Pro-inflammatory cytokines, particularly IL-6 and leukemia inhibitory factor (LIF), are secreted by both human cardiomyocytes and cardiac fibroblasts [7]. Expression and production of cytokines is controlled by external stimuli, such as catecholamines, but can also be regulated in an autocrine manner [8]. For instance, IL-1 and TNFa induce expression of IL-6 in dog cardiomyocytes [9] and modulate cell function in concert with other cytokines [8]. In a number of non cardiac cell types [1014], the IL-1-induced IL-6 secretion is strongly increased by cAMP. However, the cAMP/IL-1 synergism has never been examined in the heart. Thus, the first aim of this study was to examine the interplay between IL-1 and $\beta$-AR on IL-6 production in adult rat ventricular myocytes (ARVMs). We show that IL-1 induces IL-6 gene expression and IL-6 secretion, and this effect is strongly synergized by the $\beta$-AR/cAMP/PKA cascade.

The second aim of this study concerns the signalling pathway of IL-6 in cardiomyocytes. Two different activation pathways for IL-6 have been described 
$[15,16]$. In the classical pathway, IL-6 binds to the gp80 transmembrane IL-6 receptor (IL-6R), which leads to dimerization and activation of the signal transducing protein gp130. Whereas gp130 is ubiquitously expressed in most tissues including the heart, the IL-6R is only expressed in some cell populations. Therefore, the effect of IL-6 through the classical IL-6 activation pathway is restricted to those cells that express the IL-6R. The second IL-6 activation pathway, called IL- 6 trans-signalling, is mediated by the IL6 soluble receptor (sIL-6R) [15]. In this, IL-6 binds to sIL-6R and this IL-6/sIL-6R complex activates gp130. Therefore, cells lacking the membrane bound IL-6R can still respond to IL-6 in the presence of sIL-6R.

Whether acting via IL-6R or sIL-6R, it is generally accepted that both activation pathways converge to activate similar downstream signalling cascades, which include the JAK/STAT (Janus kinase/signal transducer and activator of transcription) pathway, the MAPK (mitogen activated protein kinase) cascade and the PI3K/AKT pathway [15]. This latter pathway can lead to activation of the p70-S6 kinase (S6K) by phosphorylation on Thr-389 site, which in turn phosphorylates the ribosomal S6 protein known to play a pivotal role in protein synthesis. S6K can also be phosphorylated by MAPK on Thr-421/Ser-424 sites [17].

It is now firmly established that IL-6-related cytokines are potent inducers of cardiac myocyte hypertrophy [18-21]. It was also reported that continuous activation of gp130 causes cardiac hypertrophy in transgenic mice overexpressing IL-6 and the sIL6R [22]. However, IL-6 does not induce a hypertrophic response in neonatal cardiomyocyte culture in the absence of sIL-6R [22]. As discussed above, this is classically considered as evidence that the IL-6R is not expressed or is not functional. However, it may also indicate that IL-6 activates different intracellular signals depending on whether it binds to IL-6R or to sIL-6R, with only the latter leading to 
cellular hypertrophy. Our second goal here was to test that hypothesis in ARVMs where the role of IL-6 itself remains poorly understood. We found that IL-6 acts via its soluble IL-6 receptor to activate the STAT3 signalling pathway and increase protein synthesis and expression of cellular markers associated with cellular hypertrophy. However, IL-6 also acts via its membrane receptor to produce a different response, i.e. phosphorylation of ERK1/2, AKT and S6K, which does not lead to hypertrophy.

\section{Materials and methods}

\subsection{Hormones and reagents}

Recombinant rat IL-1 $\beta$ and IL-6, human IL-6 and human soluble IL-6 receptor were purchased from PeproTech France (Paris, France), the Epac activator 8-(4Chlorophenylthio)-2'-O-methyladenosine-3', 5'-cyclic monophosphate (8-CPT), the PKA activator N6-monobutyryladenosine-3',5'-cyclic monophosphate (6-MB-cAMP), and the PKA inhibitor Rp-8-(4-chlorophenylthio)adenosine-3', 5'-cyclic monophosphorothioate (Rp-cAMPS) from BIOLOG Life Science Institute (Bremen, Germany), KT5720 from Tebu-Bio (Le Perray en Yvelines, France), oligonucleotides from MWG-Biotech (Ebersberg, Germany), pertussis toxin (PTX), cholera toxin (CT), dideoxyforskolin (ddFSK), JAK Inhibitor I were from Calbiochem EMD Biosciences Inc. (Darmstadt, Germany), isoprenaline (ISO), 3-isobutyl-1-methylxanthine (IBMX), forskolin (FSK) from Sigma Aldrich (Saint Quentin, France), and $\left[{ }^{3} \mathrm{H}\right]-$ leucine was from GE Healthcare Europe GMBH (Orsay, France).

\subsection{Preparation of adult rat ventricular myocytes}

All experiments were carried out according to the European Community guiding principles in the care and use of animals (86/609/CEE, CE Off $J \mathrm{n}^{\circ} \mathrm{L} 358,18$ December 
1986), the local ethics committee (CREEA Ile-de-France Sud) guidelines and the French decree n87-848 of October 19, 1987 (J Off Rép Fr, 20 October 1987, pp. 12245-12248). Authorizations to perform animal experiments according to this decree were obtained from the Ministère Français de l'Agriculture, de la Pêche et de l'Alimentation (n92-283, June 27, 2007).

Male Wistar rats (250-300 g) were anaesthetized by sodium thiopental injection $(100 \mathrm{mg} / \mathrm{kg})$. Adult rat ventricular myocytes (ARVMs) were obtained by retrograde perfusion as previously described [23]. Isolated cells were suspended in MEM medium containing $1.2 \mathrm{mM} \mathrm{Ca}{ }^{2+}, 2.5 \%$ heat-inactivated foetal calf serum, $1 \%$ penicillinstreptomycin and $20 \mathrm{mM}$ HEPES pH 7.6, and 200,000 cells were plated on laminincoated culture dishes $(10 \mu \mathrm{g} / \mathrm{ml})$ in a $95 \% \mathrm{O}_{2}, 5 \% \mathrm{CO}_{2}$ incubator at $37^{\circ} \mathrm{C}$ for $2 \mathrm{~h}$. Cells were then incubated in serum-free medium for $24 \mathrm{~h}$ before stimulation. Under these conditions, most cells remained attached and no contamination with fibroblasts was observed. In addition, serum-free medium contained $10 \mu \mathrm{g} / \mathrm{ml}$ cytosine-Darabinofuranoside to prevent potential fibroblast proliferation.

Phase-contrast photographs of cultured ARVMs were taken after $48 \mathrm{~h}$ treatment and cell surface areas were analyzed using the NIH ImageJ software (http://rsb.info.nih.gov/ij/).

\subsection{RNA extraction and RT-PCR analysis}

Total RNA from ARVMs was extracted using the RNAble kit (Eurobio, Les Ulis, France). The RNA integrity was confirmed by the microfluidic technology using the Agilent 2100 Bioanalyzer which also allows RNA quantification. Two micrograms of RNA were reverse-transcribed using the First-Strand cDNA Synthesis Kit (GE Healthcare Europe GMBH, Orsay, France). IL-6R mRNA was detected by PCR. The 
PCR conditions used were: $94^{\circ} \mathrm{C}$ for $30 \mathrm{~s}, 59^{\circ} \mathrm{C}$ for $30 \mathrm{~s}, 72^{\circ} \mathrm{C}$ for $120 \mathrm{~s}$ for 35 cycles. The amplified products were visualised by ethidium bromide/agarose gel electrophoresis and recorded under UV illumination using the ChemiDoc XRS (BioRad Laboratories, Marnes-la-Coquette, France). IL-6 and c-Fos mRNAs were quantified using real-time PCR and the SYBRGreen technology on a LightCycler rapid thermal cycler (Roche Diagnostics). The following primers were used: for IL-6R $\square$ sense (5'-CCATACCTGGAAGCCTCGTT) and antisense (5'CGTACTGATCCTCGTGGTTGT); for IL-6, sense (5'TCCTACCCCAACTTCCAATGCTC) and antisense (5'TTGGATGGTCTTGGTCCTTAGCC); for c-Fos, sense (5'GCCGGTCAAGAACATTAGCA) and antisense (5'GCTGCATAGAAGGAACCAGA). Results were normalized to cyclophilin A gene (CyA) expression with the following primers: sense (5'GAGCACTGGGGAGAAAGGAT) and antisense (5'CTTGCCATCCAGCCACTCAG).

\subsection{Assay of secreted IL-6 and BNP}

After cell stimulation, the culture medium $(2 \mathrm{ml})$ was collected, centrifuged $\left(10,000 \times \mathrm{g}\right.$ for $\left.10 \mathrm{~min}, 4^{\circ} \mathrm{C}\right)$ to remove debris, and aliquots were stored at $-80^{\circ} \mathrm{C}$ until analysed. IL-6 and brain natriuretic peptide (BNP) were assayed using commercially available enzyme-linked immunoassays (ELISA) from Endogen (Rockford, IL, USA) and Assaypro (St. Charles, MO, USA), respectively. Absorbance was measured on an automatic plate reader (Biorad SA, Ivry, France). 


\subsection{Cell extracts and Western blot analysis}

To prepare whole ARVM cell lysates, cells were lysed in cold HNTG lysis buffer containing $50 \mathrm{mM}$ Hepes $(\mathrm{pH}$ 7.5), $400 \mathrm{mM} \mathrm{NaCl}, 100 \mathrm{mM} \mathrm{NaF}, 10 \mathrm{mM}$ Napyrophosphate, $1.5 \mathrm{mM} \mathrm{MgCl} 2,1 \mathrm{mM}$ EGTA, 10\% Glycerol, 1\% Triton X100 supplemented with $1 \mathrm{mM} \mathrm{Na} \mathrm{VO}_{4}$, and a protease inhibitor mixture (1 mM AEBSF, $1 \mathrm{mM}$ benzamidine, $10 \mu \mathrm{g} / \mathrm{ml}$ soybean trypsin inhibitor, $10 \mu \mathrm{g} / \mathrm{ml}$ aprotinin, $1 \mu \mathrm{g} / \mathrm{ml}$ leupeptin, $1 \mu \mathrm{g} / \mathrm{ml}$ antipain, $1 \mu \mathrm{g} / \mathrm{ml}$ pepstatin). The lysates were centrifuged at $10,000 \times g$ for 10 min and assayed for protein concentration using bicinchoninic acidprotein reagent (Sigma Aldrich, Saint Quentin, France).

For immunoblotting assays, proteins were resolved by $4-12 \%$ or $8-16 \%$ SDSPAGE (Lonza Verviers, Verviers, Belgium), transferred onto nitrocellulose membranes, and stained with 3\% Ponceau S (Sigma Aldrich, Saint Quentin, France). The membranes were saturated with $3 \%$ bovine serum albumin. Phosphorylation of STAT3 (Tyr705), ERK1/2 (Thr202/Tyr204), S6K (Thr421/Ser424), S6K (Thr389), AKT (Ser473), PKA substrate (RRXS/T) and cardiac troponin I (Ser23/24) (TnI) was detected using specific antibodies from Cell Signaling Technology (Beverly, MA, USA). IL-6R was detected using specific antibodies (M-20) from Santa Cruz Biotechnology (Santa Cruz, CA, USA). GAPDH expression was revealed using monoclonal antibodies from Sigma Aldrich. Immunoreactive proteins were revealed using a 1:20,000 dilution of anti-rabbit or anti-mouse IgG peroxidase conjugate antibodies (Promega Corp., Madison, USA), and were visualized with Supersignal West Pico reagent (Perbio Science, Vigneux, France). The membranes were stripped and reprobed with specific antibodies against STAT3, ERK1/2, AKT, S6K (Cell Signaling Technology) or calsequestrin (CS) (Affinity BioReagents, Ozyme, Saint-Quentin- 
Fallavier, France). Densitometric analyses of Western blots were performed using the NIH ImageJ software.

\section{6. $\left[{ }^{3} H\right]$-Leucine incorporation}

Protein synthesis was assessed by adding labelled leucine to the culture medium and measuring its incorporation into the total trichloroacetic acid (TCA)-precipitable ARVM protein. Triplicate culture wells $(100,000$ cells $)$ were serum-deprived for $24 \mathrm{~h}$, and then incubated for $24 \mathrm{~h}$ with agonists. Pulse labelling with $\left[{ }^{3} \mathrm{H}\right]$-leucine $(2 \mu \mathrm{Ci} / \mathrm{ml})$ was carried out for $4 \mathrm{~h}$ before harvesting of the cells. ARVMs were washed twice with ice-cold phosphate-buffered saline, incubated overnight and then washed with 5\% TCA. Precipitates were solubilized by incubation in $0.1 \mathrm{~N} \mathrm{NaOH}, 0.1 \%$ Triton $\mathrm{X} 100$ for 30 min, and the radioactivity was counted by liquid scintillation (Beckman Instruments, Inc., Fullerton, CA, USA). The radioactivity was normalized to the DNA content, measured using Quant-iT PicoGreen dsDNA reagent from Invitrogen (Cergy-Pontoise, France). The ratio of $\left[{ }^{3} \mathrm{H}\right]$-leucine incorporated/DNA from untreated cells was set as $100 \%$, and the results were expressed as fold-increase relative to untreated controls.

\subsection{Statistical analysis}

Results are given as mean \pm SEM. Paired Student's $t$-test was used to compare different treatments. Differences with $\mathrm{p}$ values $<0.05$ were considered as statistically significant. The number of culture replicates in a given experiment, and the number of independent experiments performed are indicated in the figure legends. A synergy index (SI) was defined as the ratio of the IL-6 mRNA or protein induced by IL-1 (minus control value) measured in the presence and absence of ISO. A synergy index of 1 indicated no synergy. 


\section{Results}

3.1. IL-6 gene expression and secretion are synergistically induced by $I L-1$ and $\beta-A R$ stimulation in ARVMs

IL-6 mRNA expression in ARVMs was measured by real-time PCR following a 4h cell stimulation with either IL-1 (40 $\mathrm{ng} / \mathrm{ml})$ or isoprenaline (ISO, $1 \mu \mathrm{M})$, or both. Since the maximum IL-6 mRNA rate was observed 3 to $5 \mathrm{~h}$ following stimulation (not shown), the cells were routinely stimulated for $4 \mathrm{~h}$. Figure $1 \mathrm{~A}$ shows that treating the cells with IL-1 induced a $\sim 5$-fold induction of IL-6 gene expression ( $p<0.05$ ), whereas ISO alone had a small and non-significant effect. However, a concomitant application of ISO and IL-1 induced a synergistic $~ 12$-fold induction of IL-6 gene expression. The synergy index (SI), as defined in the Materials and methods section was 2.8 .

To determine whether the IL-1/ISO synergistic effect on IL-6 gene expression also resulted in an increase in the level of IL-6 protein, the secretion of IL- 6 by ARVMs was measured in the culture medium after a 16h-stimulation with either IL-1, ISO, or both. Figure 1B shows that treating ARVMs with ISO alone induced a low but significant $(\mathrm{p}<0.05)$ increase in IL-6 secretion $\left(0.27 \pm 0.03 \mathrm{ng} / \mathrm{ml}\right.$ IL- 6 secreted by $2 \times 10^{5}$ cells, i.e. a 1.5 -fold increase over basal). When the cells were treated with IL-1, IL-6 secretion increased 8-fold $(\mathrm{p}<0.05)$. However, a concomitant treatment of ARVMs with ISO and IL-1 induced a much larger increase in IL-6 secretion $(5.3 \pm 1.2 \mathrm{ng} / \mathrm{ml} \mathrm{IL-6}$ secreted by $2 \times 10^{5}$ cells, i.e. $~ 29$-fold increase over basal). Therefore, ISO and IL-1 have a clear synergistic effect also on IL-6 secretion (SI=3.9). This synergistic effect was dose-dependent with respect to ISO (Fig. 1C), with a half-maximal effect (EC50) obtained at $\sim 10 \mathrm{nM}$ ISO, and a maximal increase at >100 nM ISO. 
3.2. Involvement of the $G / d c A M P / P K A$ pathway in the IL-1/ISO synergistic effect on $I L$ 6 secretion in ARVMs

$\beta$-ARs are classically coupled to $G_{s}$ proteins that activate adenylyl cyclase leading to activation of PKA by cAMP. However, $\beta$-ARs (particularly $\beta_{2}$ - and $\beta_{3}$-ARs) can also couple to pertussis toxin (PTX)-sensitive $\mathrm{G}_{\mathrm{i}} / \mathrm{G}_{\mathrm{o}}$ proteins, which subsequently activate MAPK or PI3K cascades [24,25]. Therefore, we examined whether the IL-1/ISO synergistic effect on IL-6 secretion was due to $G_{s}$ and/or $G_{i} / G_{o}$ protein activation. As shown in Fig. 2A, incubation of ARVMs with $2 \mu \mathrm{g} / \mathrm{ml}$ cholera toxin (CT), which ADPribosylates and activates $\mathrm{G}_{\mathrm{s}}$ proteins, mimicked the effect of ISO on IL-6 secretion, producing little effect when applied alone but strongly amplifying the effect of IL-1. Conversely, preincubation of the cells with $100 \mathrm{ng} / \mathrm{ml}$ PTX, which ADP-ribosylates and inhibits $G_{i} / G_{0}$ proteins, had no effect, neither on basal IL-6 secretion, nor on the synergistic effect of ISO+IL-1. These results indicate that $\mathrm{G}_{\mathrm{s}}$ proteins, but not $\mathrm{G}_{\mathrm{i}} / \mathrm{G}_{\mathrm{o}}$ proteins, are responsible for the IL-1/ISO synergistic effect on IL-6 production in ARVMs.

To evaluate the contribution of cAMP in this process, the effect of $1 \mu \mathrm{M}$ ISO was compared with that of $10 \mu \mathrm{M}$ forskolin (FSK), a direct activator of adenylyl cyclase, or $100 \mu \mathrm{M}$ IBMX, a non-selective cyclic nucleotide phosphodiesterase inhibitor. As shown in Fig. 2B, ELISA analysis after a 16h-stimulation of ARVMs showed that FSK and IBMX mimicked the effect of ISO on IL-6 secretion, producing moderate effects when applied alone ( $\sim 0.4 \mathrm{ng} / \mathrm{ml}$ IL-6 secreted by $2 \times 10^{5}$ cells) corresponding to respectively, 3- and 2.8-fold induction, but strongly amplifying the effect of IL-1 (respectively, 15and 12-fold induction), similarly to ISO (11-fold induction). In contrast to FSK, $10 \mu \mathrm{M}$ dideoxyforskolin (ddFSK), a structural analog of FSK that does not activate adenylyl cyclase, had no effect by itself either on IL-6 secretion nor on IL-1-stimulated IL-6 
secretion. To confirm the biological impact of the different pharmacological compounds used above, ARVMs were stimulated with either $10 \mu \mathrm{M}$ FSK, $100 \mu \mathrm{M}$ IBMX, $1 \mu \mathrm{M}$ ISO or $10 \mu \mathrm{M}$ ddFSK, and proteins were extracted and analysed by Western blot using antibodies for phospho-Troponin I (TnI), known to be activated by cAMP-dependent phosphorylation via PKA. As shown in Fig. 2C, FSK, IBMX and ISO clearly increased TnI phosphorylation, but ddFSK had no effect. These experiments strongly support the involvement of the cAMP cascade in the IL-1/ISO synergistic effect on IL-6 production.

Cyclic AMP can produce biological effects either by activating PKA phosphorylation or via a direct binding and activation of the Rap-1 guanine-exchange factor EPAC. To examine which of these two mechanisms was involved, we compared the effect of two cAMP analogues: 8-CPT, a selective EPAC activator which does not activate PKA [26]; 6-MB-cAMP, a selective PKA activator which does not activate EPAC [27]. As a positive control, the inset in Fig. 3A shows that ISO and 6-MB-cAMP increased TnI phosphorylation, but 8-CPT did not. Similarly, ISO and 6-MB-cAMP increased phosphorylation of PKA substrates, but 8-CPT did not (not shown). As shown in Fig. 3A, $10 \mu \mathrm{M}$ 8-CPT had neither no effect by itself on IL-6 secretion, and did not increase the effect of IL-1 on IL-6 secretion. Even a 20-fold higher concentration (200 $\mu \mathrm{M}$ ) of 8 -CPT had no effect on IL-6 secretion induced by IL-1 (not shown). Conversely, 6-MB-cAMP $(200 \mu \mathrm{M})$ induced a marked increase in IL-1-stimulated IL-6 secretion $(\mathrm{SI}=6.7)$. Figure 3B shows that preincubation of ARVMs for $2 \mathrm{~h}$ with $50 \mu \mathrm{M}$ Rp-cAMPS, a competitive inhibitor of PKA type I and II, significantly decreased the synergistic effect of IL-1 and ISO on IL-6 secretion. The presence of Rp-cAMPS reduced the SI value from 4.8 to 2.2. No significant effect of Rp-cAMPS on IL-1stimulated IL-6 secretion was observed while the low effect of ISO on IL-6 secretion was decreased by 50\%. The inset in Fig. 3B shows that $10 \mu \mathrm{M}$ KT5720 (KT), another 
selective PKA inhibitor, also decreased the synergistic effect of IL-1 and ISO on IL-6 secretion by $\sim 2$ fold. To confirm the inhibition of PKA activity by Rp-cAMPS, protein extracts from control cells or cells pretreated with Rp-cAMPS and then treated with ISO, IL-1 or IL-1+ISO were analysed by Western blot using an antibody specifically directed against a PKA-phosphorylated motif. Figure 3C shows that ISO and IL-1+ISO enhanced PKA-dependent protein phosphorylation and that this effect was inhibited (by $\sim 40-50 \%$ as calculated by the ImageJ software) by Rp-cAMPS. We conclude that the cAMP/PKA pathway, but not the cAMP/EPAC pathway, is involved in the ISO/IL-1 synergistic effect on IL-6 secretion in ARVMs.

\subsection{IL-6 signalling pathways in ARVMs}

IL-6 binds to a gp80 transmembrane receptor (IL-6R) and to a soluble IL-6 receptor (sIL-6R). The latter turns on a signal transduction mechanism named IL-6 trans-signalling. Both receptors trigger cellular responses by forming a functional complex with two gp130 subunits, leading to the activation of the JAK/STAT, MAPK and PI3K pathways [15]. To get some insights into the mechanisms of action of IL-6 in ARVMs, we first examined whether the gp80 transmembrane IL-6 receptor was expressed in these cells. Figure 4A shows that a transcript of 614 bp was detected by RT-PCR with the IL-6R primers. As a positive control, transcripts of IL-6R were also examined in PC12 cells, which are known to express the receptor [28]. Using antibodies directed against gp80 IL-6R, we found that both ARVMs and PC12 cells expressed the gp80 protein at similar levels (Fig. 4B).

Next, we explored whether the IL-6R was able to stimulate MAPK phosphorylation, known to be activated by IL-6 in other cell types. Western blot analysis of phosphorylated MAPK was performed following treatment of ARVMs for 
increasing times with rat IL-6 (rIL-6), using antibodies raised against ERK1/2 phosphorylated on Thr202/Tyr204 residues. Figure 4C shows that $100 \mathrm{ng} / \mathrm{ml}$ rIL-6 induced ERK1/2 phosphorylation in ARVMs which occurred within 10 min and was maintained for at least $1 \mathrm{~h}$. IL-6 was also shown to activate the PI3K/AKT pathway in various cell types including neonatal rat cardiomyocytes [29]. This pathway is involved in the control of the activity of a number of proteins, such as S6K. Furthermore, it was reported that simultaneous stimulation of the MEK/ERK and PI3K/AKT cascades is required for S6K activation [30]. Therefore, we studied by Western blot analysis the phosphorylation of AKT on Ser473 and of S6K on Thr389 and Thr421/Ser424 residues [17] in ARVMs exposed to rIL-6. Figure 4D shows that phosphorylation of AKT increased after a 10-min application of rIL-6 and was maintained for at least $1 \mathrm{~h}$. As shown in Fig. 4E, rIL-6 also induced S6K phosphorylation on both Thr389 and Thr421/Ser424 residues, but with a slower time course.

Since STAT3 phosphorylation on Tyr705 is essential for dimerisation and activation of STAT3, we examined whether activation of the transmembrane IL-6 receptor was able to activate STAT3 phosphorylation. Figure 5A shows a typical Western blot experiment on ARVMs exposed for increasing times to rIL-6. As shown, activation of IL-6R had no effect on STAT3 phosphorylation. We therefore tested the hypothesis that STAT3 phosphorylation required activation of IL-6 trans-signalling, using a combination of human IL-6 (hIL-6) plus the human soluble IL-6 receptor (hsIL6R). The rationale for using the human cytokine and its corresponding soluble receptor rather than their rat counterparts is because the rat soluble IL-6 receptor is not commercially available. As shown in Fig. 5B, activation of IL-6 trans-signalling induced a rapid phosphorylation of STAT3 that reached a maximum at 20-30 min and lasted for at least $6 \mathrm{~h}$. On average, hIL-6/hsIL-6R induced a $~ 4.5$-fold activation of 
STAT3 phosphorylation, as evaluated by densitometric analysis of the Western blots, while rIL-6 had no effect (Fig. 5C). The effect of hIL-6/hsIL-6R was clearly due to IL-6 trans-signalling since hIL-6 alone (like rIL-6) had no effect on STAT3 phosphorylation (not shown). Moreover, in agreement with the well established lack of effect of rodent IL-6 on human cells, rIL-6 in combination with hsIL-6R was also unable to activate STAT3 phosphorylation (not shown). Finally, the effects of IL-6R on ERK1/2, AKT and S6K phosphorylation and of IL-6 trans-signalling on STAT3 phosphorylation involved activation of the JAK proteins, since all phosphorylations were abolished by the JAK inhibitor I (Fig. 5D).

3.4. IL-6 trans-signalling induces c-Fos mRNA expression, protein synthesis, BNP secretion and increases cell size in ARVMs

Our above results demonstrate that the downstream events differ depending on whether IL-6 acts via its transmembrane receptor or via the IL-6 trans-signalling. To examine which of these two pathways is involved in cardiac hypertrophy, we compared the capacity of IL-6 and IL-6 trans-signalling to activate markers known to be associated with cardiac hypertrophy. As a control, we used the $\alpha_{1}$-adrenergic agonist phenylephrine (PE) known to induce cardiomyocyte hypertrophy [31]. As expected, a 90 min exposure of ARVMs to $100 \mu \mathrm{M}$ PE led to a strong ( 6-fold) induction of the cfos gene (Fig. 6A), an immediate early gene which expression is reported to precede hypertrophic responses [32]. Similarly, a 24h incubation of ARVMs with PE significantly increased $\left[{ }^{3} \mathrm{H}\right]$-leucine incorporation by the myocytes (by $\sim 30 \%$, Fig. 6B), a well-known index of protein synthesis. Finally, a 48h stimulation of ARVMs with PE increased cell size by $\sim 32 \%$ (Fig. $6 \mathrm{C}$ ) and $\sim 3.5$-fold the secretion of brain natriuretic peptide (BNP, Fig. 6D), which is part of the fetal gene program reactivated during 
cardiac hypertrophy [33]. While PE activated all four markers of cellular hypertrophy, $100 \mathrm{ng} / \mathrm{ml}$ of either rIL-6 or hIL-6 alone had no effect (Fig. 6A-D). However, a combination of hIL-6 and its soluble receptor hsIL-6R induced a marked and significant increase in all parameters (Fig. 6 A-D). These results indicate that the IL-6 transsignalling, but not the IL-6 transmembrane receptor, leads to hypertrophy in ARVMs.

\section{Discussion}

In this report, we describe a synergistic action of the $\beta$-AR/cAMP pathway and IL-1 on IL-6 secretion in isolated ARVMs. Furthermore, we show that IL-6 activates two different signalling pathways in adult cardiomyocytes: in the presence of its soluble receptor, IL-6 induces STAT3 phosphorylation and activates cellular markers of cardiac hypertrophy; in the absence of its soluble receptor, IL-6 activates a separate pathway leading to phosphorylation of ERK1/2, AKT and S6K.

As shown earlier in neonatal rat cardiomyocytes [34] and mouse cardiac fibroblasts [2], ISO, FSK and IBMX, which all increase intracellular cAMP, had little effect by themselves on IL-6 secretion in ARVMs. However, when ARVMs were exposed to IL-1 plus ISO, the amount of IL-6 secreted increased by an order of magnitude, and reached the level reported in cultured human cardiomyocytes from patients with chronic ischemic heart disease [7]. A similar synergistic effect of cAMP and IL-1 on IL-6 secretion has been documented in several non-cardiac cell types, such as mesangial [10], Caco-2 [11], hippocampal [12], and thyroid FRTL-5 cells [13,14]. In isolated ARVMs, the half-maximum synergistic effect was obtained with $\sim 9 \mathrm{nM}$ ISO, a concentration which is similar to the plasma levels of noradrenaline and adrenaline $(\sim 8$ nM) measured in cachectic patients with chronic heart failure [35]. 
Our results demonstrate the involvement of the $\mathrm{G}_{\mathrm{s}}$ protein/adenylyl cyclase/cAMP cascade in the ISO/IL-1 synergistic effect on IL-6 secretion. In cardiomyocytes, cAMP activates two independent signalling pathways involving either PKA or EPAC $[26,36]$. EPAC was recently shown to be involved in IL-6 release in response to activation of the $\beta_{2}$-AR in the RAW murine macrophage cell line [37]. However, we found no evidence in ARVMs for the participation of EPAC in the synergistic effect of cAMP and IL-1 on IL-6 production. In contrast, the cAMP/PKA pathway was clearly involved, as demonstrated using the PKA-selective agonist, 6-MB-cAMP and the PKA-selective inhibitor, Rp-cAMPS. Rp-cAMPS did not totally inhibit the synergistic effect of cAMP/IL-1 on IL-6 production (Fig. 3B), but this was due to an incomplete inhibition of PKA-dependent protein phosphorylation (Fig. 3C). IL-6 gene expression is known to be regulated both at the transcriptional and post-transcriptional level [38]. In ARVMs, we found that enhanced IL-6 protein synthesis and secretion were related to an increase in IL-6 mRNA levels (Fig. 1 and 2). In neonatal rat cardiomyocytes, it has been shown that activation of the AP- 1 and CRE response elements located in the IL-6 promoter is necessary and sufficient for ISO-mediated induction of IL-6 [34].

IL-6 plays an important role in the pathogenesis of heart failure. IL-6 plasma levels are increased in patients with congestive heart failure [6], and measurement of IL-6 levels now provides a diagnostic tool for cardiac diseases [39]. However, the contribution of IL-6 to the progression of hypertrophy in cardiomyocytes and the signal transduction mechanisms involved remain unknown. In this study, we found that ARVMs express the transmembrane IL-6 receptor, both at the mRNA and protein level. Moreover, the IL-6R appeared functional, since IL-6 alone induced ERK1/2, AKT and S6K phosphorylation. ERK1/2 phosphorylation may result in S6K phosphorylation on Thr421/Ser424 residues, which are localized in the pseudosubstrate domain of S6K, and 
when phosphorylated may lead to subsequent S6K phosphorylation on Thr389 residues and kinase function [17,30]. Indeed, we found that IL-6 stimulation of ARVMs induced phosphorylation of S6K on Thr421/Ser424 and Thr389 residues as well as phosphorylation of the upstream kinase AKT on Ser473. All these effects were blocked by the JAK inhibitor I demonstrating the involvement of gp130-JAKs. Therefore, IL-6 signalling was fully operational in ARVMs, even in the absence of sIL-6R.

Although IL-6 alone activated MAPK, and activation of MAPK is classically involved in cardiac hypertrophy [40], IL-6 alone did not activate hypertrophy markers. Recent evidence in mouse heart indicates that ERK1/2 phosphorylation of the threonine and tyrosine residues in the TEY motif of the activation loop (residues 202-204 in rat ERK2) is not sufficient to lead to cardiac hypertrophy but requires in addition autophosphorylation of ERK1/2 (on Thr188 in mouse ERK2), a process that may be limited to certain upstream signals, such as $\mathrm{G}_{\mathrm{q}}$-coupled receptor activation [41]. In ARVMs, activation of the hypertrophic markers by IL-6 required the presence of sIL6R and was linked to phosphorylation of STAT3. Like in neonatal rat cardiomyocytes [42], IL-6 alone was unable to phosphorylate STAT3 in ARVMs. However, in ARVMs treated with the IL-6/sIL-6R complex, phosphorylation of STAT3 occurred within minutes and lasted for several hours (Fig. 5), suggesting an important role of phosphoSTAT3. Indeed, we observed that IL-6/sIL-6R, but not IL-6 alone, induced c-fos gene expression, BNP secretion and protein synthesis. All three parameters are considered as typical markers of cardiomyocyte hypertrophy, and, as expected, they were similarly activated in ARVMs treated with phenylephrine. In neonatal rat cardiomyocytes, LIF and CT-1, which are members of the IL-6-related cytokine family, were also found to increase protein synthesis $[21,43,44]$ and BNP secretion $[43,45]$. We also showed that 
IL-6/sIL-6R increased ARVMs surface area and this effect was similar to that reported for CT-1 in neonatal rat cardiomyocytes [43].

In summary, our study demonstrates for the first time a cross-talk between IL-1 and the $\beta$-AR signalling pathway in adult ventricular myocytes which leads to a synergistic induction of IL-6 production by mechanisms involving $\mathrm{G}_{\mathrm{s}}$ proteins and cAMP/PKA pathway (Fig. 7). Analysis of the IL-6 signalling pathways led to the finding that IL-6 increased STAT3 phosphorylation, protein synthesis, hypertrophic cellular markers, and hypertrophy of ARVMs but required to do so the presence of sIL6R (Fig. 7). The IL-6 soluble receptor may thus serve as a switch for IL-6 to activate STAT3 phosphorylation and hypertrophy. These findings may have obvious clinical implications, since elevated levels of sIL-6R have been reported in patients with hypertrophic or idiopathic dilated cardiomyopathies [46] as well as in heart failure patients [47]. 


\section{Acknowledgments}

We would like to thank Dr Jean-Paul Blondeau for valuable advice and critical reading of the manuscript. We thank Charlotte Lagrange and Lorna Dufait for their excellent technical contribution, Claudine Deloménie and the IFR141 transcriptome core facility for their help in real time RT-PCR experiments, and Valérie DomergueDupont and the IFR141 animal core facility for providing efficient animal care.

This work was supported by a grant from the Fondation Leducq (06CVD02 cycAMP). 


\section{References}

[1] D.R. Murray, S.D. Prabhu, B. Chandrasekar, Circulation 101 (2000) 2338-2341.

[2] F. Yin, P. Li, M. Zheng, L. Chen, Q. Xu, K. Chen, Y.Y. Wang, Y.Y. Zhang, C. Han, J Biol Chem 278 (2003) 21070-5.

[3] S.D. Prabhu, Circ Res 95 (2004) 1140-53.

[4] K. Shan, K. Kurrelmeyer, Y. Seta, F. Wang, Z. Dibbs, A. Deswal, D. LeeJackson, D.L. Mann, Curr Opin Cardiol 12 (1997) 218-23.

[5] A.M. Terrell, P.R. Crisostomo, G.M. Wairiuko, M. Wang, E.D. Morrell, D.R. Meldrum, Shock 26 (2006) 226-34.

[6] R.S. Vasan, L.M. Sullivan, R. Roubenoff, C.A. Dinarello, T. Harris, E.J. Benjamin, D.B. Sawyer, D. Levy, P.W. Wilson, R.B. D'Agostino, Circulation 107 (2003) 1486-91.

[7] C. Ancey, P. Corbi, J. Froger, A. Delwail, J. Wijdenes, H. Gascan, D. Potreau, J.C. Lecron, Cytokine 18 (2002) 199-205.

[8] C.S. Long, Heart Fail Rev 6 (2001) 81-94.

[9] M. Gwechenberger, L.H. Mendoza, K.A. Youker, N.G. Frangogiannis, C.W. Smith, L.H. Michael, M.L. Entman, Circulation 99 (1999) 546-551.

[10] C. Grassl, B. Luckow, D. Schlondorff, U. Dendorfer, J Am Soc Nephrol 10 (1999) 1466-77.

[11] D.D. Hershko, B.W. Robb, G. Luo, P.O. Hasselgren, Am J Physiol Regul Integr Comp Physiol 283 (2002) R1140-8.

[12] A. Bergamaschi, M. Corsi, M.J. Garnier, Cell Signal 18 (2006) 1679-84.

[13] N. Szabo-Fresnais, J.P. Blondeau, M. Pomérance, Mol Cell Endocrinol 284 (2008) 28-37.

[14] M. Iwamoto, T. Sakihama, N. Kimura, K. Tasaka, T. Onaya, Cytokine 3 (1991) 345-9.

[15] P.C. Heinrich, I. Behrmann, S. Haan, H.M. Hermanns, G. Muller-Newen, F. Schaper, Biochem J 374 (2003) 1-20.

[16] C. Drucker, J. Gewiese, S. Malchow, J. Scheller, S. Rose-John, J Autoimmun 2009) (in press, PMID: 19717281).

[17] A. Dufner, G. Thomas, Exp Cell Res 253 (1999) 100-9.

[18] D. Pennica, K.L. King, K.J. Shaw, E. Luis, J. Rullamas, S.M. Luoh, W.C. Darbonne, D.S. Knutzon, R. Yen, K.R. Chien, J.B. Baker, W.I. Wood, Proc Natl Acad Sci USA 92 (1995) 1142-6. 
[19] K.C. Wollert, H. Drexler, Heart Fail Rev 6 (2001) 95-103.

[20] M.R. Bristow, C.S. Long, Circulation 106 (2002) 1430-2.

[21] H. Kodama, K. Fukuda, J. Pan, S. Makino, A. Baba, S. Hori, S. Ogawa, Circ Res 81 (1997) 656-63.

[22] H. Hirota, K. Yoshida, T. Kishimoto, T. Taga, Proc Natl Acad Sci USA 92 (1995) 4862-6.

[23] I. Verde, G. Vandecasteele, F. Lezoualc'h, R. Fischmeister, Br J Pharmacol 127 (1999) 65-74.

[24] Y. Daaka, L.M. Luttrell, R.J. Lefkowitz, Nature 390 (1997) 88-91.

[25] R.P. Xiao, Sci STKE 2001 (2001) RE15.

[26] J. de Rooij, F.J. Zwartkruis, M.H. Verheijen, R.H. Cool, S.M. Nijman, A. Wittinghofer, J.L. Bos, Nature 396 (1998) 474-477.

[27] A.E. Christensen, F. Selheim, J. de Rooij, S. Dremier, F. Schwede, K.K. Dao, A. Martinez, C. Maenhaut, J.L. Bos, H.G. Genieser, S.O. Doskeland, J Biol Chem 278 (2003) 35394-402.

[28] P. Marz, R.A. Gadient, U. Otten, Brain Res 706 (1996) 71-9.

[29] N. Smart, M.H. Mojet, D.S. Latchman, M.S. Marber, M.R. Duchen, R.J. Heads, Cardiovasc Res 69 (2006) 164-77.

[30] J.A. Lehman, V. Calvo, J. Gomez-Cambronero, J Biol Chem 278 (2003) 281308.

[31] A.J. Barron, S.G. Finn, S.J. Fuller, Biochem J 371 (2003) 71-9.

[32] T. Brand, H.S. Sharma, W. Schaper, J Mol Cell Cardiol 25 (1993) 1325-37.

[33] P.H. Sugden, A. Clerk, J Mol Med 76 (1998) 725-746.

[34] S. Rohrbach, S. Engelhardt, M.J. Lohse, K. Werdan, J. Holtz, U. MullerWerdan, Mol Med 13 (2007) 605-14.

[35] S.D. Anker, P.P. Ponikowski, A.L. Clark, F. Leyva, M. Rauchhaus, M. Kemp, M.M. Teixeira, P.G. Hellewell, J. Hooper, P.A. Poole-Wilson, A.J. Coats, Eur Heart J 20 (1999) 683-93.

[36] F. Lezoualc'h, M. Métrich, I. Hmitou, N. Duquesnes, E. Morel, J Mol Cell Cardiol 44 (2008) 623-32.

[37] K.S. Tan, A.G. Nackley, K. Satterfield, W. Maixner, L. Diatchenko, P.M. Flood, Cell Signal 19 (2007) 251-60.

[38] W. Vanden Berghe, L. Vermeulen, G. De Wilde, K. De Bosscher, E. Boone, G. Haegeman, Biochem Pharmacol 60 (2000) 1185-95. 
[39] J.W. Petersen, G.M. Felker, Congest Heart Fail 12 (2006 ) 324-8.

[40] J. Heineke, J.D. Molkentin, Nat Rev Mol Cell Biol 7 (2006) 589-600.

[41] K. Lorenz, J.P. Schmitt, E.M. Schmitteckert, M.J. Lohse, Nat Med 15 (2009) 7583.

[42] Z. Sheng, K. Knowlton, J. Chen, M. Hoshijima, J.H. Brown, K.R. Chien, J Biol Chem 272 (1997) 5783-91.

[43] N. Takahashi, Y. Saito, K. Kuwahara, M. Harada, K. Tanimoto, Y. Nakagawa, R. Kawakami, M. Nakanishi, S. Yasuno, S. Usami, A. Yoshimura, K. Nakao, J Mol Cell Cardiol 38 (2005) 185-92.

[44] E. Hiraoka, S. Kawashima, T. Takahashi, Y. Rikitake, T. Hirase, M. Yokoyama, Kobe J Med Sci 49 (2003) 25-37.

[45] Y. Nakaoka, K. Nishida, Y. Fujio, M. Izumi, K. Terai, Y. Oshima, S. Sugiyama, S. Matsuda, S. Koyasu, K. Yamauchi-Takihara, T. Hirano, I. Kawase, H. Hirota, Circ Res 93 (2003) 221-9.

[46] M. Hogye, Y. Mandi, M. Csanady, R. Sepp, K. Buzas, Am J Cardiol 94 (2004) 249-51.

[47] M. Rivera, R. Talens-Visconti, R. Sirera, V. Bertomeu, A. Salvador, R. Cortes, F. Garcia de Burgos, V. Climent, R. Paya, L. Martinez-Dolz, M.J. Sancho-Tello, A. Gonzalez-Molina, Eur J Heart Fail 6 (2004) 877-82. 


\section{Figure Legends}

Fig. 1. Effects of IL-1 and ISO on IL-6 mRNA expression and secretion. ARVMs $\left(2 \times 10^{5}\right.$ cells) were incubated in serum-free medium for $24 \mathrm{~h}$ before stimulation. A, B: stimulation with $1 \mu \mathrm{M}$ ISO, or $40 \mathrm{ng} / \mathrm{ml} \mathrm{IL-1,} \mathrm{or} \mathrm{both} \mathrm{(IL-1+ISO),} \mathrm{for} 4 \mathrm{~h}$ (A) or $16 \mathrm{~h}$ (B). C: stimulation with $40 \mathrm{ng} / \mathrm{ml} \mathrm{IL-1} \mathrm{and} \mathrm{increasing} \mathrm{concentrations} \mathrm{of} \mathrm{ISO.} \mathrm{The}$ synergy index (SI) is defined in the "Materials and Methods" section. A: after treatment, total IL-6 mRNA was quantified using real-time PCR. Results, corrected for the expression of cyclophilin A (CyA) mRNA, are expressed relative to the values measured in untreated cells (Ctrl), and are the means \pm S.E.M. of three independent experiments, each run in triplicate. B, C: after treatment, the concentration of IL-6 was measured by ELISA in the culture medium. Secreted IL-6 was expressed in $\mathrm{ng} / \mathrm{ml}$ of culture medium. The values are the means \pm S.E.M. of 3 independent experiments. Statistical analysis: *, p <0.05; **, p $<0.01$ vs. Ctrl; \#, p<0.05 vs. IL-1.

Fig. 2. Involvement of Gs/cAMP signalling pathways in the secretion of IL-6. A: ARVMs were untreated (Ctrl) or treated with $40 \mathrm{ng} / \mathrm{ml} \mathrm{IL-1,} 2 \mu \mathrm{g} / \mathrm{ml} \mathrm{CT}, 1 \mu \mathrm{M}$ ISO alone or in combination for $16 \mathrm{~h}$. Where indicated, the cells were pretreated for $16 \mathrm{~h}$ with $100 \mathrm{ng} / \mathrm{ml}$ PTX before addition of the drugs. B, C: ARVMs were stimulated for 16h (B) or $10 \mathrm{~min}(\mathrm{C})$ with the following drugs, alone or in combination, as indicated: $40 \mathrm{ng} / \mathrm{ml}$ IL-1, $1 \mu$ M ISO, $10 \mu$ M FSK, $10 \mu \mathrm{M}$ ddFSK, $100 \mu$ M IBMX. A, B: the concentration of secreted IL-6 was measured by ELISA in the culture medium. The values are the mean \pm S.E.M of 3 independent experiments. Statistical analysis: \#, $\mathrm{p}<0.05$; \#\#, $\mathrm{p}<$ 0.01; vs. IL-1-treated cells; ns, $\mathrm{p}>0.05$. C: Total proteins of ARVMs were extracted and equal amounts of proteins were analysed by Western blot using antibodies for 
phospho-Troponin I (P-TnI). Calsequestrin (CS) was used as a loading control. Similar results were obtained in 3 independent experiments.

Fig. 3. Involvement of the PKA signalling pathway in the synergistic effect of IL-1/ISO on IL-6 secretion. A: ARVMs were stimulated or not (Ctrl) for $16 \mathrm{~h}$ or 10 min (inset) with $1 \mu \mathrm{M}$ ISO, $40 \mathrm{ng} / \mathrm{ml}$ IL-1, $10 \mu \mathrm{M}$ 8-CPT, $200 \mu \mathrm{M}$ 6-MB-cAMP, alone or in combination as indicated. B, C: ARVMs were pretreated or not for $2 \mathrm{~h}$ with $50 \mu \mathrm{M} \mathrm{Rp}$ cAMPS or with $10 \mu \mathrm{M}$ KT 5720 (KT: B, inset), and then treated or not (Ctrl) for $16 \mathrm{~h}$ with $1 \mu \mathrm{M}$ ISO, $40 \mathrm{ng} / \mathrm{ml}$ IL-1 or both (IL-1+ISO) as indicated. A, B, B inset: secreted IL-6 concentration was measured by ELISA in the culture medium. The values are the mean \pm S.E.M of 3 independent experiments. Statistical analysis: *, p<0.05. C, A inset: Total proteins were extracted and equal amounts were analysed by Western blot using antibodies for phospho-TnI (A inset) or phospho-PKA substrates (C). Calsequestrin (CS) was used as a loading control. Similar results were obtained in 2 independent experiments.

Fig. 4. Expression of IL-6 receptor and phosphorylation of ERK1/2, AKT and S6K in response to IL-6. A: Total RNA from PC12 cells (used as a positive control) or from ARVMs was extracted and reverse-transcribed (RT+) or not (RT-) as a negative control. IL-6R and cyclophilin A (CyA) mRNAs were amplified by PCR with specific primers and revealed with ethidium bromide as described in "Materials and Methods" section. The size of one marker is shown in bp. Similar results were obtained in 2 independent experiments. B: Total proteins were extracted from PC12 cells or ARVMs, and $50 \mu \mathrm{g}$ of proteins were analysed by Western blot for IL-6R and GAPDH expression. A representative blot from 3 independent experiments is shown. C, D, E: ARVMs were 
treated with $100 \mathrm{ng} / \mathrm{ml}$ of rat IL-6 (rIL-6) for different times, as indicated. Whole proteins were extracted and $50 \mu \mathrm{g}$ of proteins were analysed by Western blot using specific antibodies directed to phospho-ERK1/2 ${ }^{\mathrm{Thr} 202 / \mathrm{Tyr} 204}(\mathrm{C})$, phospho-AKT $^{\mathrm{Ser} 473}$ (D), phospho-S6K $^{\text {Thr389 }}$ (black bars) or phospho-S6K ${ }^{\text {Thr421/Ser424 }}$ (grey bars) (E). The membranes were stripped and reprobed with anti-ERK1/2, anti-AKT, or anti-S6K antibodies. A representative blot for each experiment is shown. Similar results were obtained from 3 to 4 independent experiments. Quantification of autoradiographs is shown with corresponding bars positioned under the bands. The intensity of the phosphorylated signal was normalized by that of the total protein. Data are given as mean \pm SEM. Statistical analysis: $*, \mathrm{p}<0.05, * *, \mathrm{p}<0.01 v s$. no stimulation (time 0 ).

Fig. 5. Effect of IL-6 and IL-6 trans-signalling on tyrosine phosphorylation of STAT3. ARVMs were treated with $100 \mathrm{ng} / \mathrm{ml}$ rat IL-6 (rIL-6) (A) or with $100 \mathrm{ng} / \mathrm{ml}$ human IL-6 (hIL-6) in the presence of $180 \mathrm{ng}$ of human soluble IL-6 receptor (hsIL-6R) (B) for increasing times, as indicated. Whole proteins were extracted and $50 \mu \mathrm{g}$ of proteins were analysed by Western blot using antibodies for phospho-STAT3 ${ }^{\text {Tyr705 }}$ (P-STAT3). The membranes were stripped and reprobed with anti-STAT3 antibody used as a loading control. A representative blot is shown, and 3 separate experiments were performed, giving similar results. C: P-STAT3/STAT3 ratios were quantified in 3 independent experiments performed as in (A, B) and expressed (mean \pm SEM) as \% of the values measured at time 0 . Statistical analysis: $0.01<\mathrm{p}<0.05$ for all the points corresponding to the stimulation with hIL-6+hsIL-6R (filled symbols); $p>0.05$ for all points corresponding to the stimulation with rIL-6. D : ARVMs were pretreated or not for $1 \mathrm{~h}$ with $5 \mu \mathrm{M}$ JAK inhibitor I and then treated with rIL-6 or with hIL-6 plus hsIL6R for 10 min (P-Stat3, P-ERK1/2, P-AKT) or for 30 min (P-S6K). Phosphorylation of 
STAT3, ERK1/2, AKT, S6K and expression of CS (as loading control) were analysed by Western blot. Similar results were obtained from 2 independent experiments.

Fig. 6. c-Fos gene expression, protein synthesis, cell surface area and BNP secretion in response to IL-6 trans-signalling. Serum was withdrawn for $24 \mathrm{~h}$ before stimulation of ARVMs with $100 \mu \mathrm{M}$ PE, $100 \mathrm{ng} / \mathrm{ml}$ rIL-6 or $100 \mathrm{ng} / \mathrm{ml} \mathrm{hIL-6}$ in presence or absence of $180 \mathrm{ng}$ hsIL-6R, as indicated. A: After $30 \mathrm{~min}$ of stimulation, total RNA was extracted and reverse-transcribed. c-Fos mRNA was quantified using real-time PCR and the results of the c-Fos mRNA quantification were corrected for the expression of cyclophilin A mRNA. c-Fos mRNA is expressed as a \% of the values measured in untreated cells (control). For each group, summary data of two independent experiments are shown, each performed in triplicate. Statistical analysis: $* p<0.05$ versus untreated cells. B: $\left[{ }^{3} \mathrm{H}\right]$-leucine incorporation in ARVMs was measured after a $24 \mathrm{~h}$-period of treatment. The radioactivity is normalized to DNA content and the ratio of $\left[{ }^{3} \mathrm{H}\right]$-leucine incorporation/DNA from untreated cells is set as $100 \%$. The results are expressed as \% increase $v s$. unstimulated cells (control). Values are the mean \pm SEM of two independent experiments, each performed in triplicate culture wells. C: Cell surface areas of ARVMs were analyzed using NIH ImageJ software. A total of approximately 200 cells were examined for each group. D: After a 48h-stimulation period, BNP concentration was determined by ELISA in the culture medium. Secreted BNP was expressed as $\%$ increase $v s$. untreated cells (control). The values are the mean \pm S.E.M of 3 independent experiments. Statistical analysis: **, $\mathrm{p}<0.01 ; *, \mathrm{p}<0.05$ vs. unstimulated cells. For each group, summary data of three independent experiments are shown, each performed in triplicate. Statistical analysis: $* \mathrm{p}<0.05$ versus untreated cells.

Fig. 7. Schematic diagram showing the regulation of IL-6 production in adult cardiomyocytes by $\beta$-adrenergic and IL- $1 \beta$ receptors and the involvement of IL- 6 transsignalling in the induction of cellular hypertrophy. IL-1 induced IL-6 secretion and $\beta$ adrenergic receptors ( $\beta$-AR) synergistically increased IL-1-induced IL-6 secretion by a mechanism involving the heterotrimeric Gs protein, cAMP and PKA. IL-6 binds either 
to its membrane-bound IL-6 receptor (IL-6R), or to the IL-6 soluble receptor (sIL-6R). The IL-6/IL-6R complex induces phosphorylation of ERK1/2, AKT and S6K via the receptor subunits gp130 and JAK proteins. However, but this does not lead to cellular hypertrophy. Although not tested, the IL-6/sIL-6R complex (IL-6 trans-signalling) may also activate phosphorylation of ERK1/2, AKT and S6K, but it activates in addition STAT3 signalling pathway which is necessary for activation of cellular hypertrophy. 
A

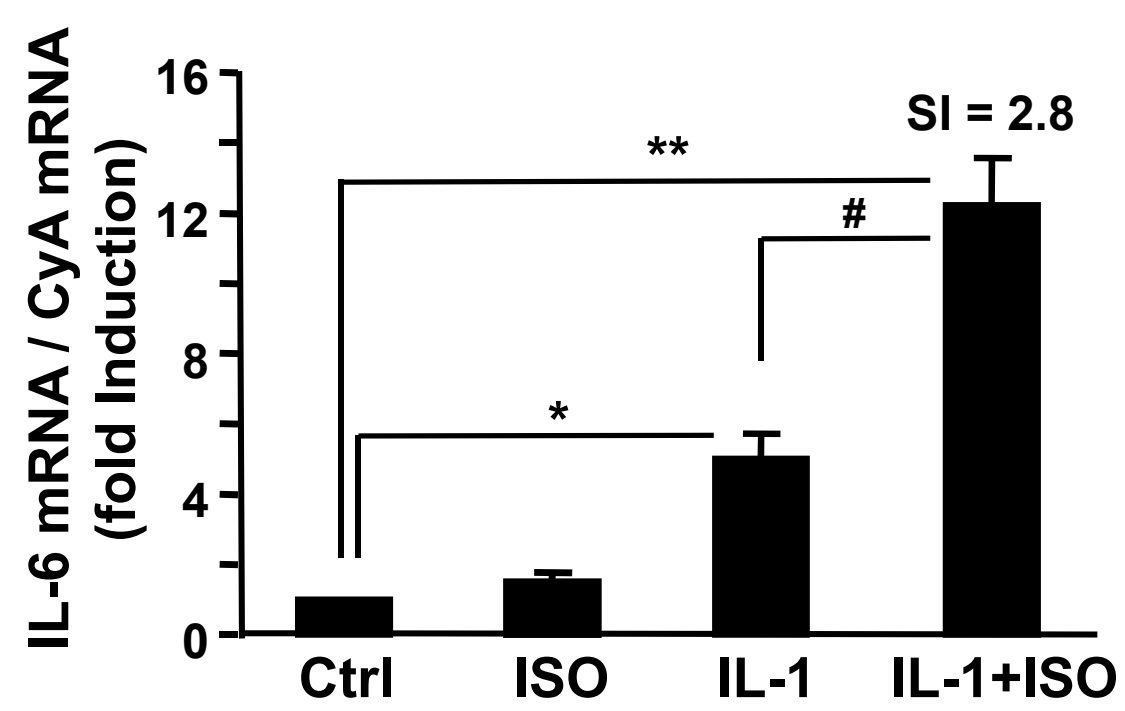

B

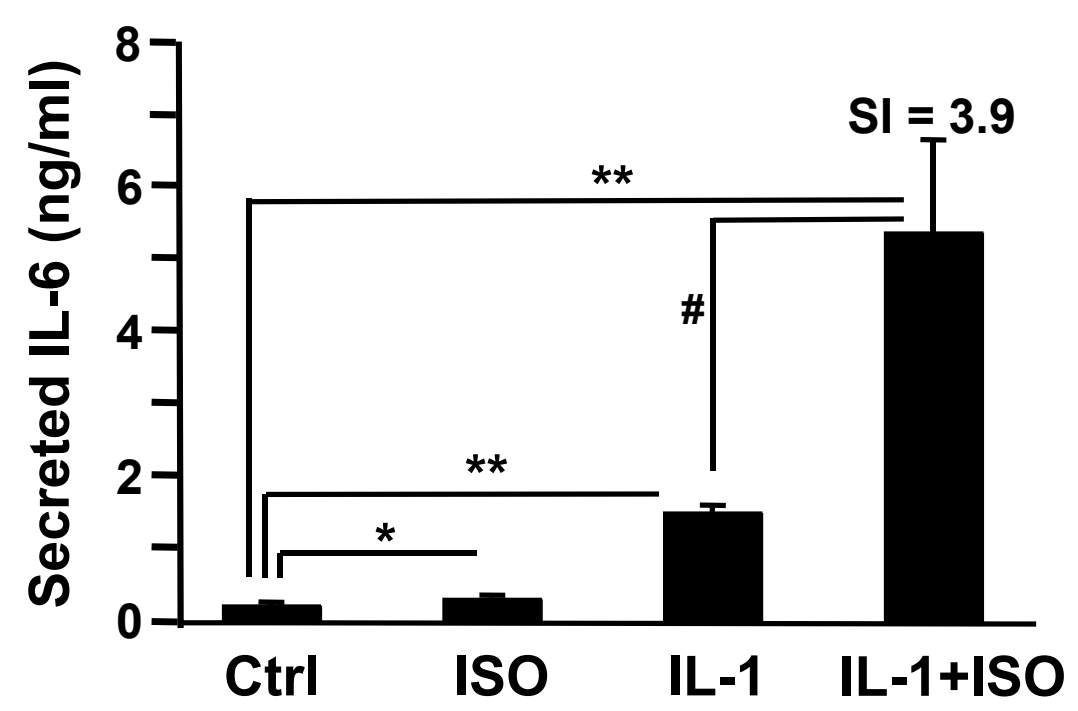

C

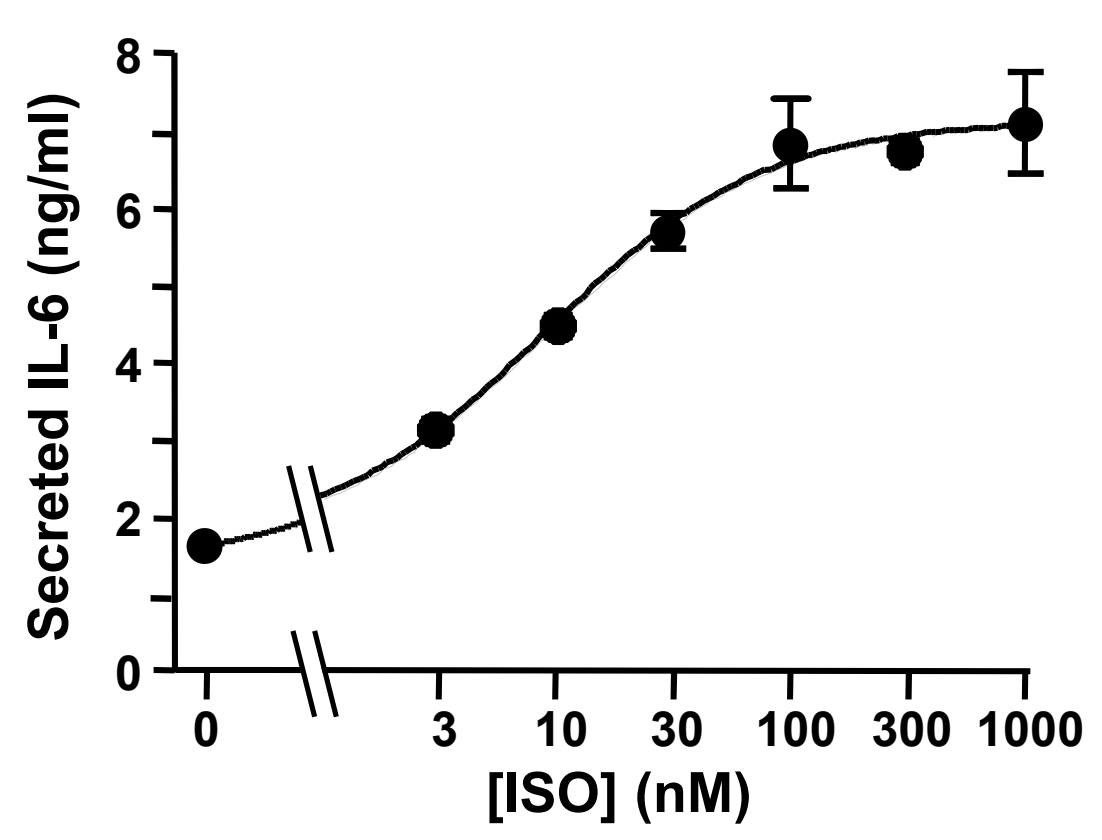

Figure 1 
A

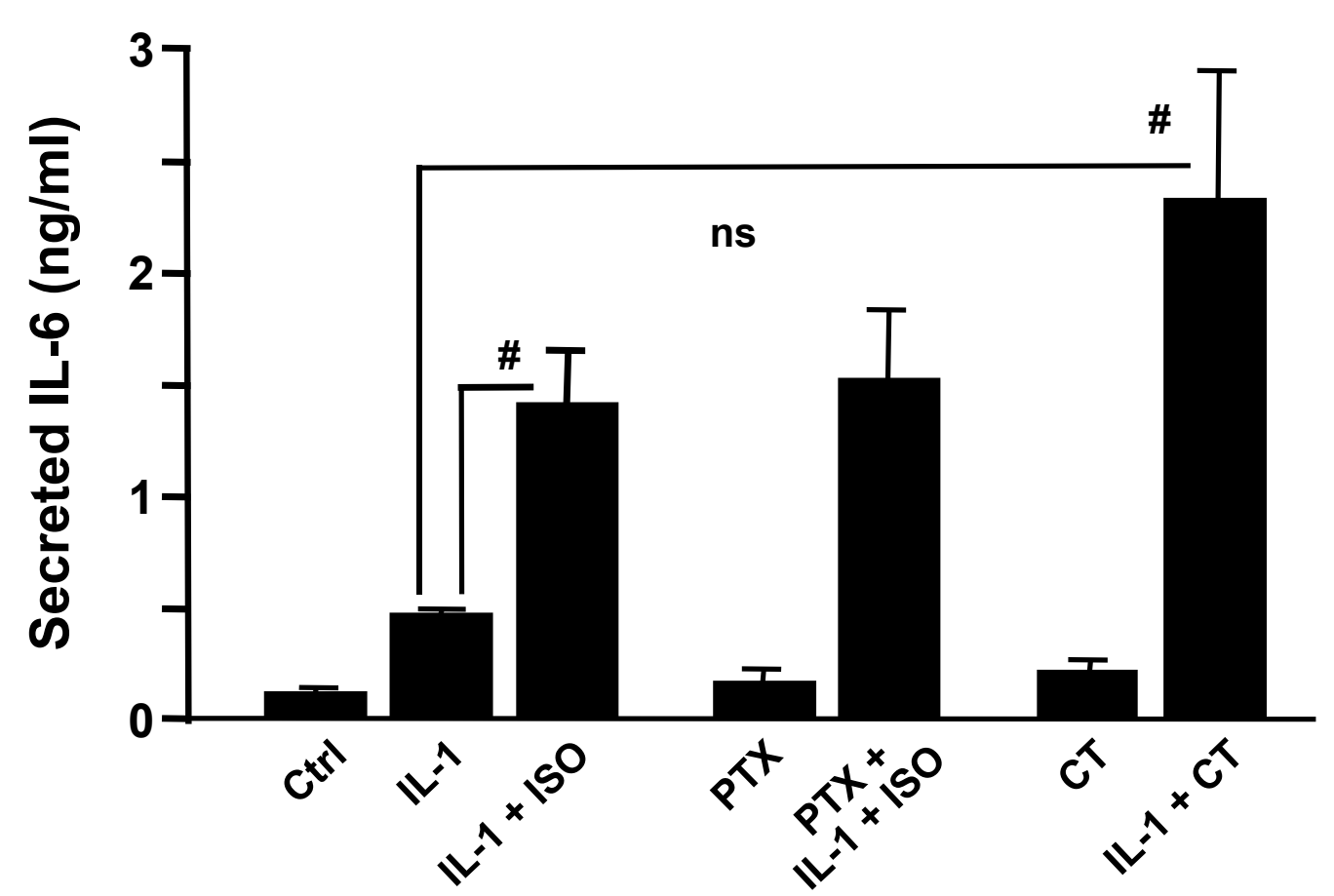

B

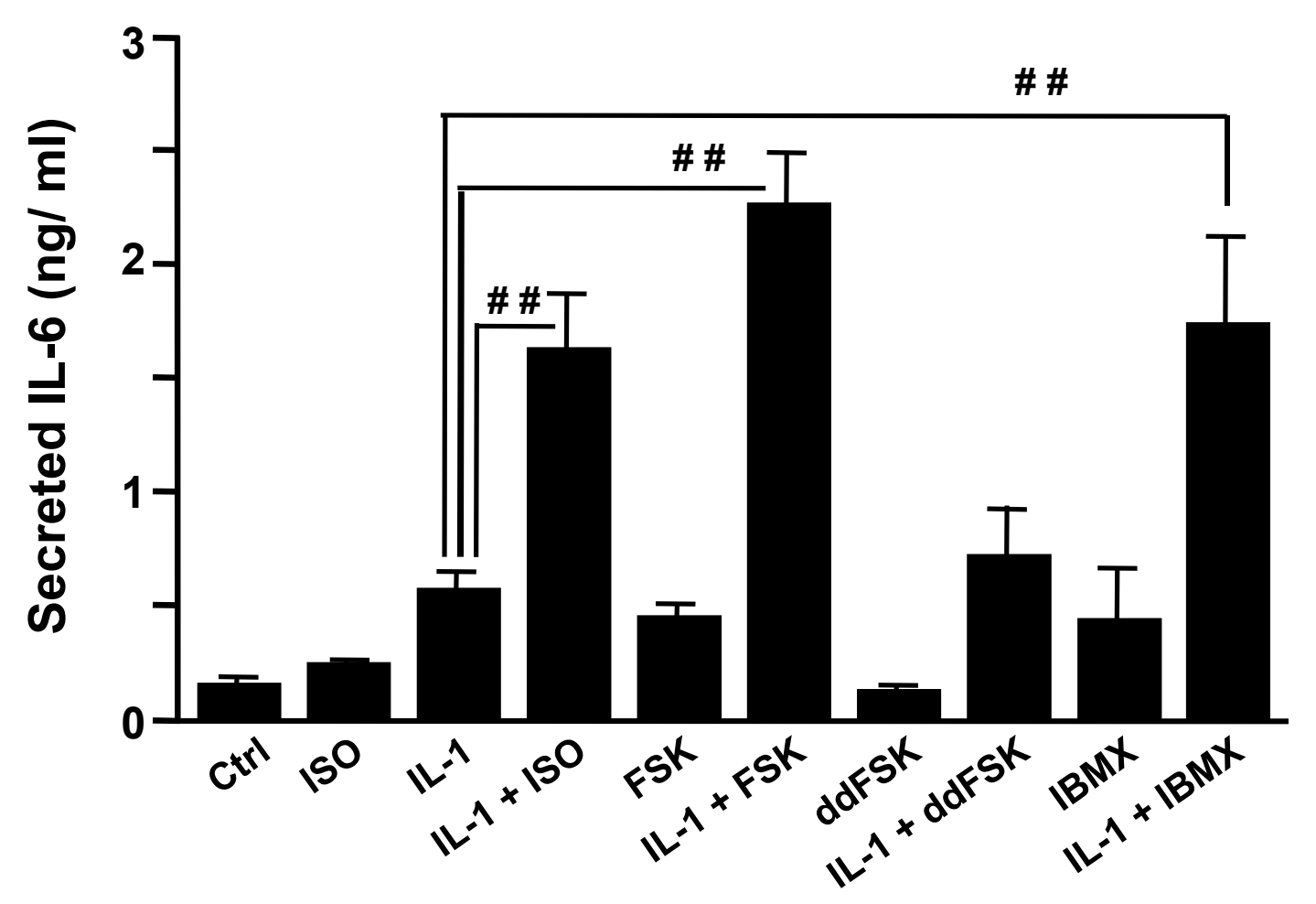

C

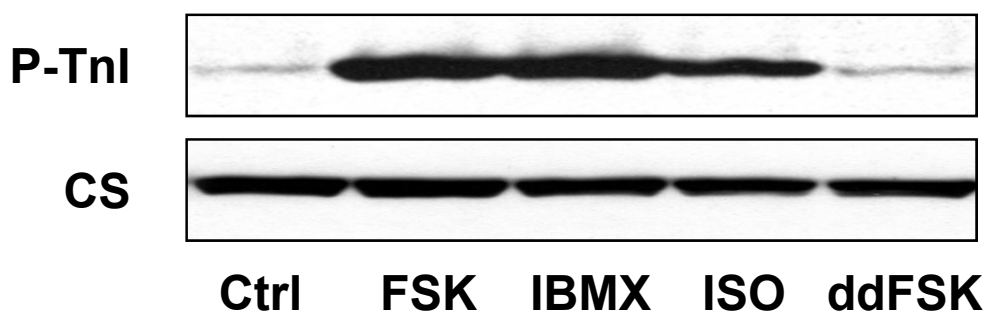

Figure 2 
A

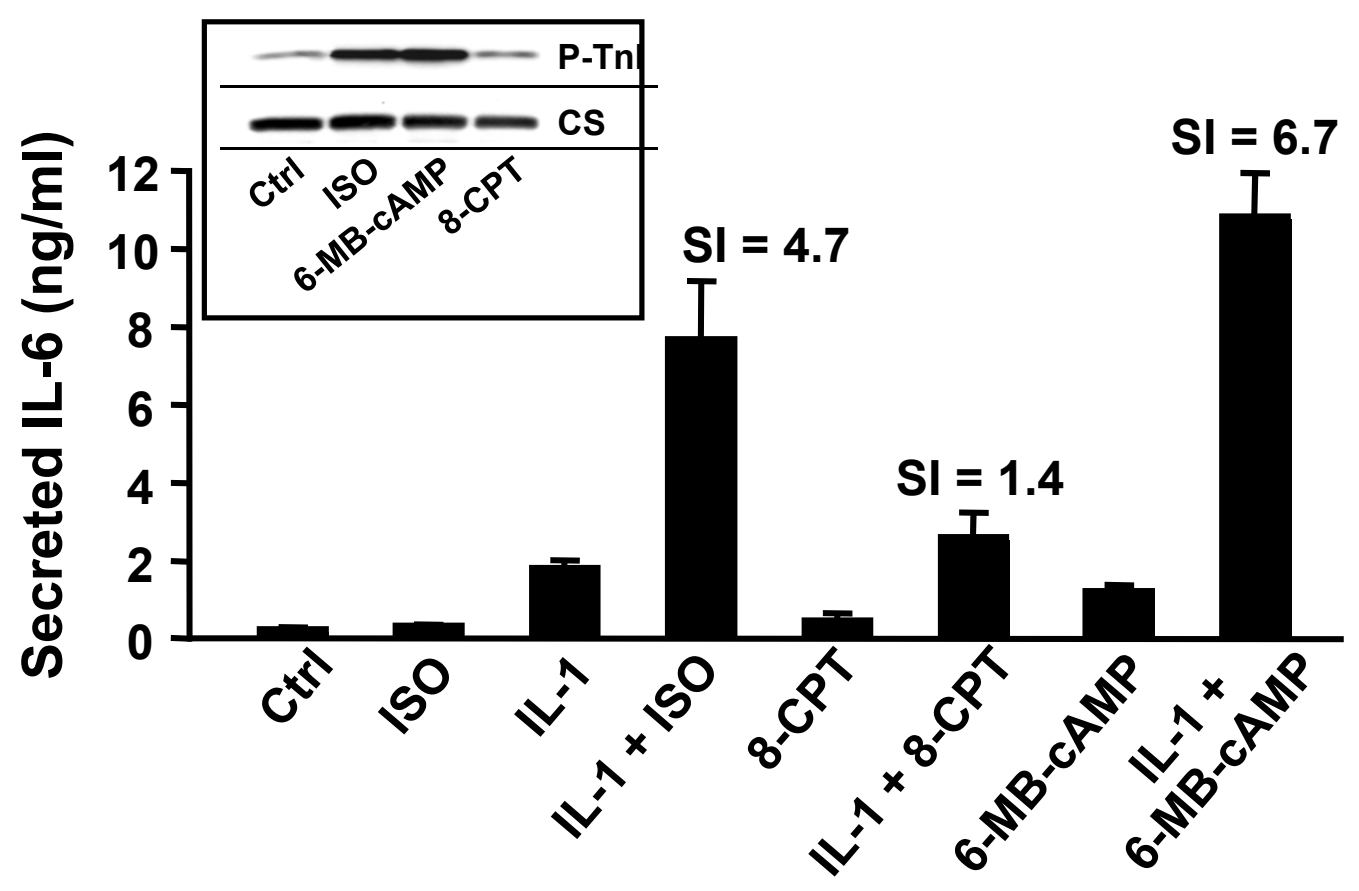

B

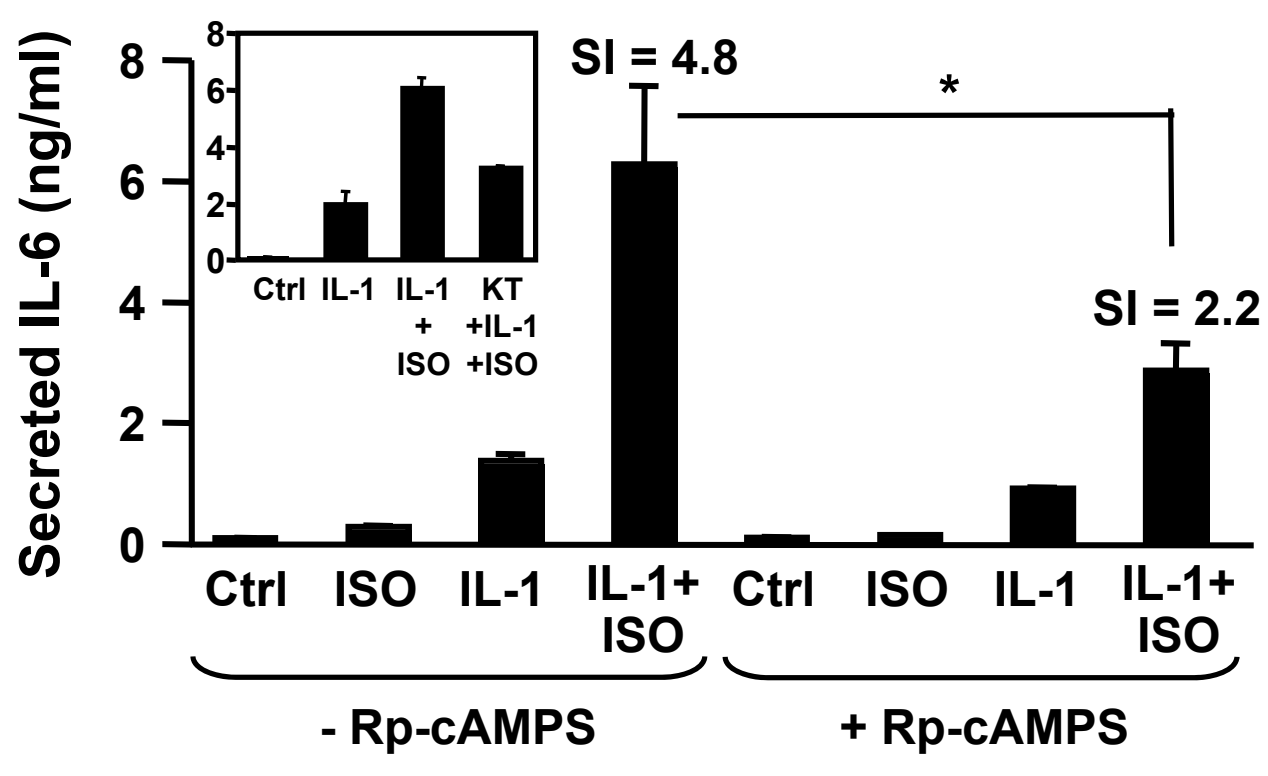

C

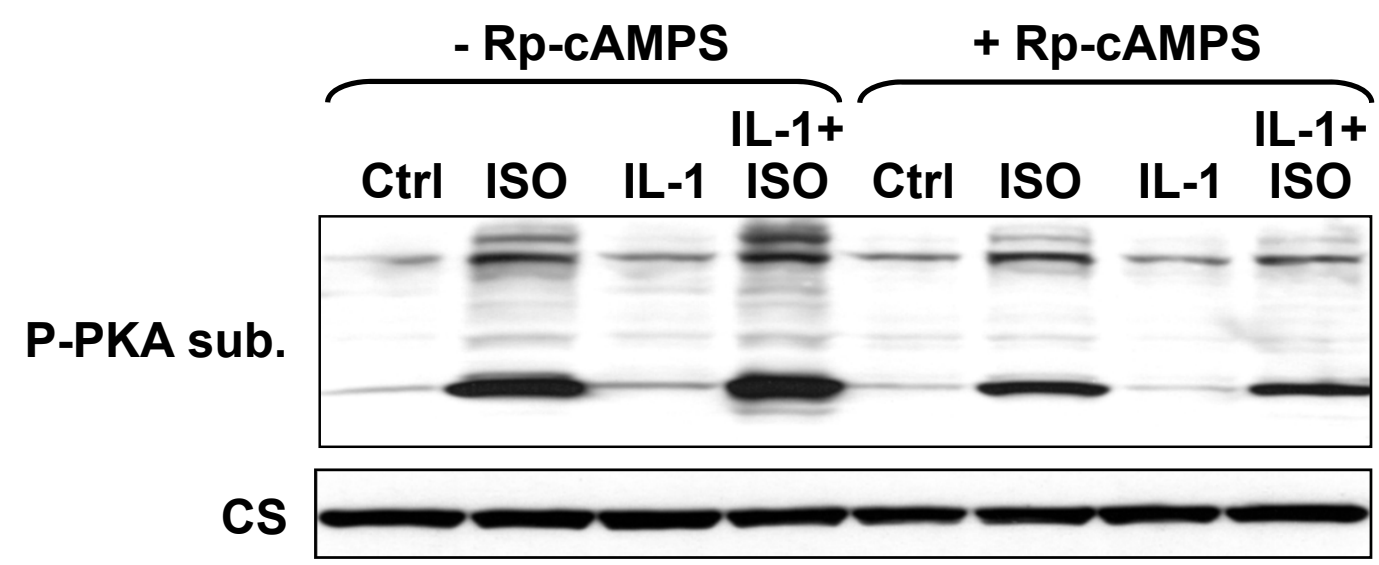

Figure 3 
A

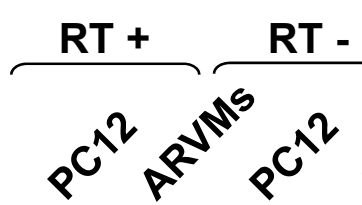

mRNA rIL-6R
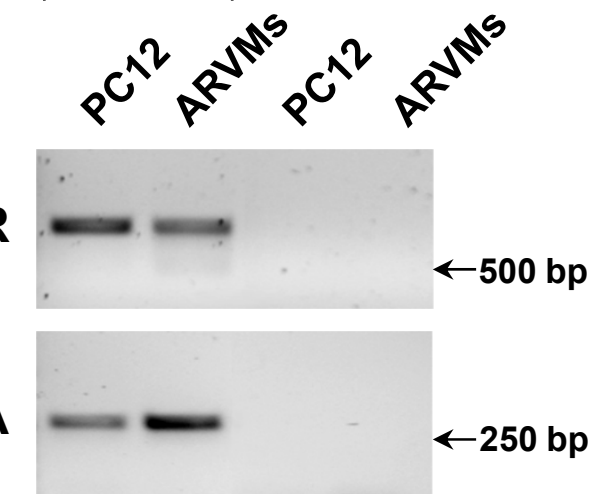

mRNA CyA
B

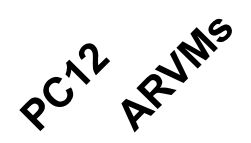

IL-6R

(gp80)

$\leftarrow 100 \mathrm{kDa}$

GAPDH
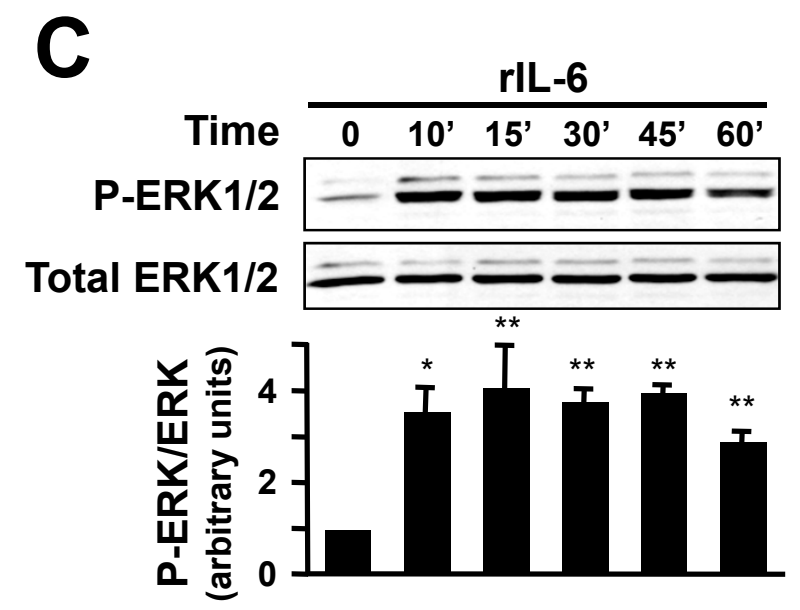

D
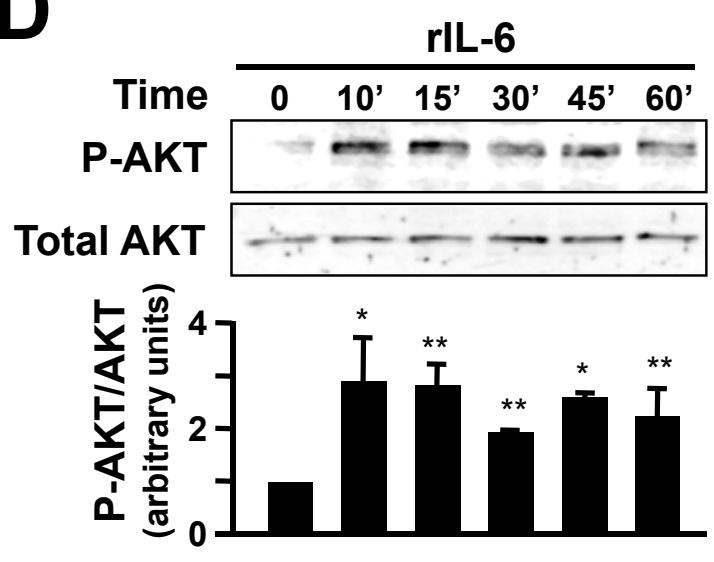
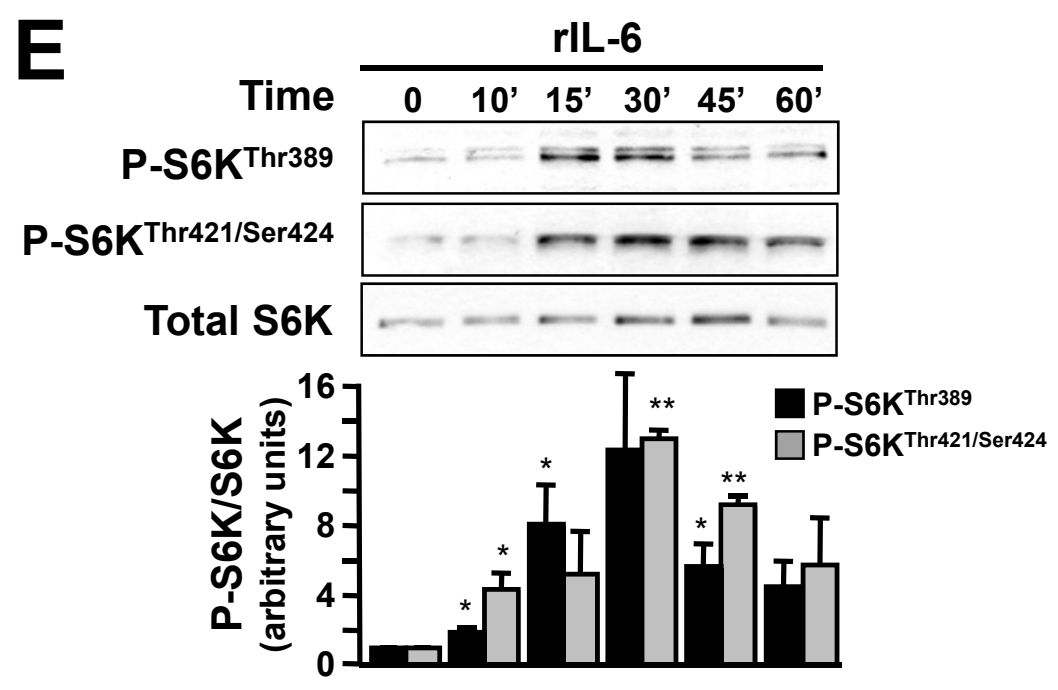

Figure 4 
A

rIL-6

B

hIL-6 + hsIL-6R

Time $\quad 0 \quad 10^{\prime} 20^{\prime} 30^{\prime}, 1 \mathrm{~h} 2 \mathrm{~h} 3 \mathrm{~h} 4 \mathrm{~h} 6 \mathrm{~h}$

0 10' 20'30' 1h $2 \mathrm{~h} 3 \mathrm{~h} 4 \mathrm{~h} 6 \mathrm{~h}$

P.STAT3 - - - - - -

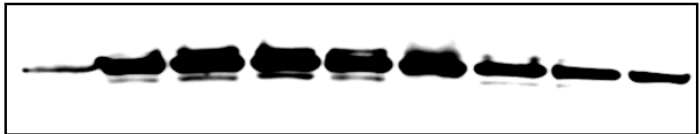

STAT3
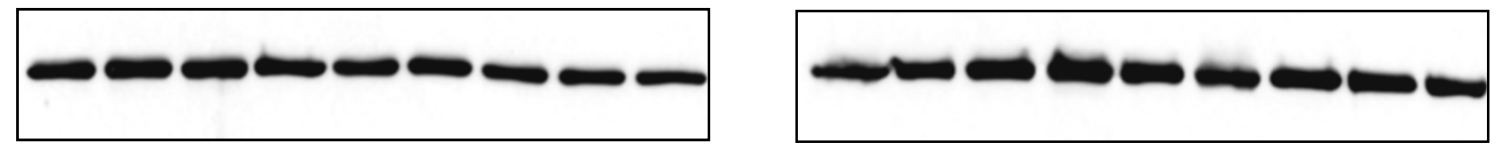

C

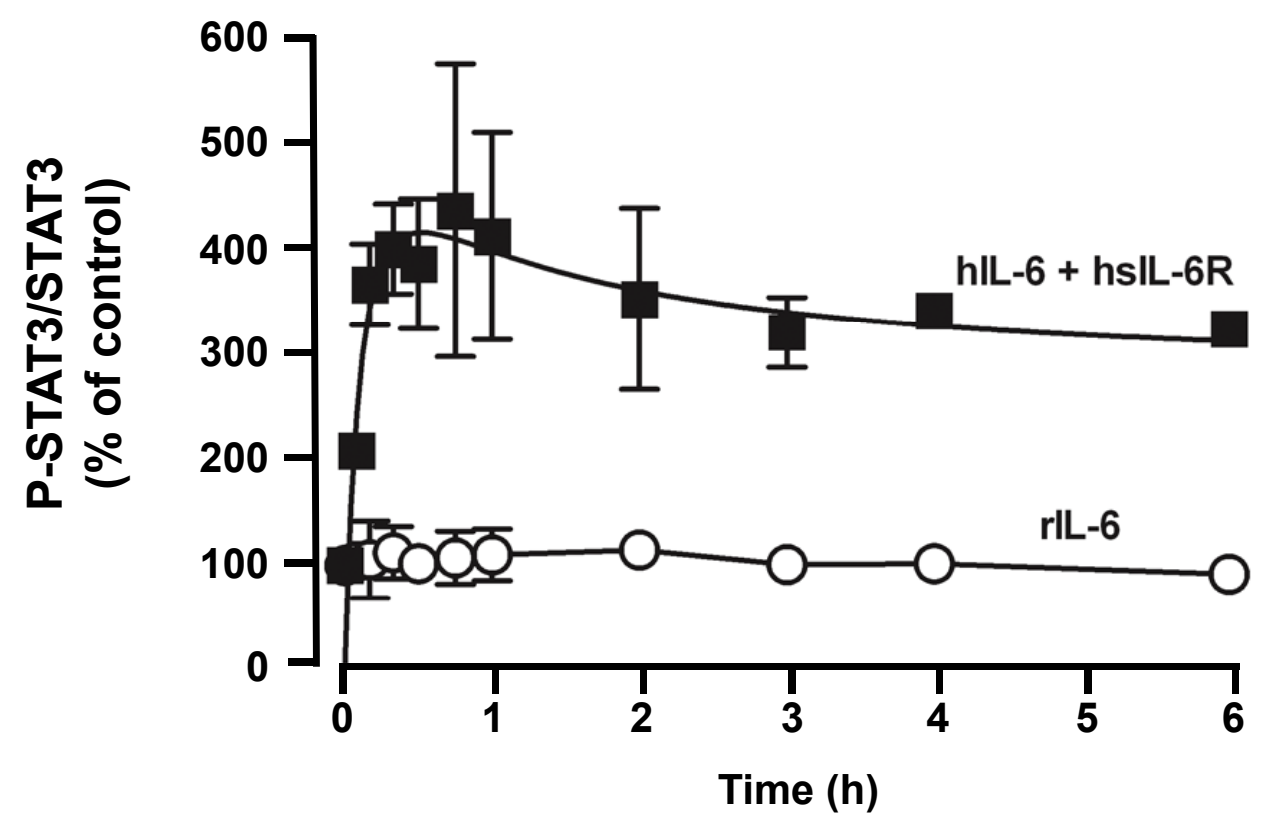

Figure 5

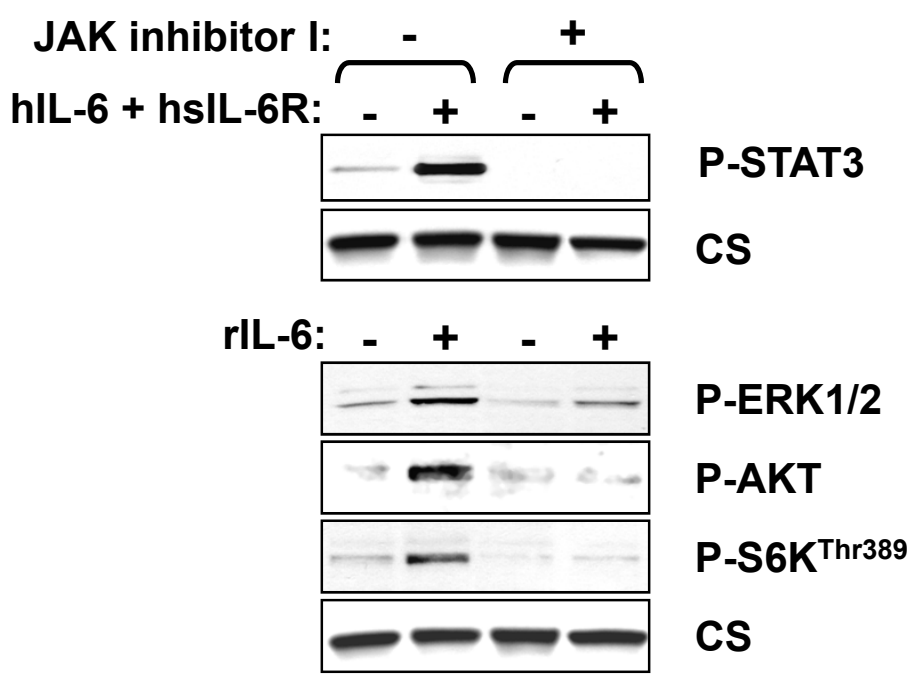


A

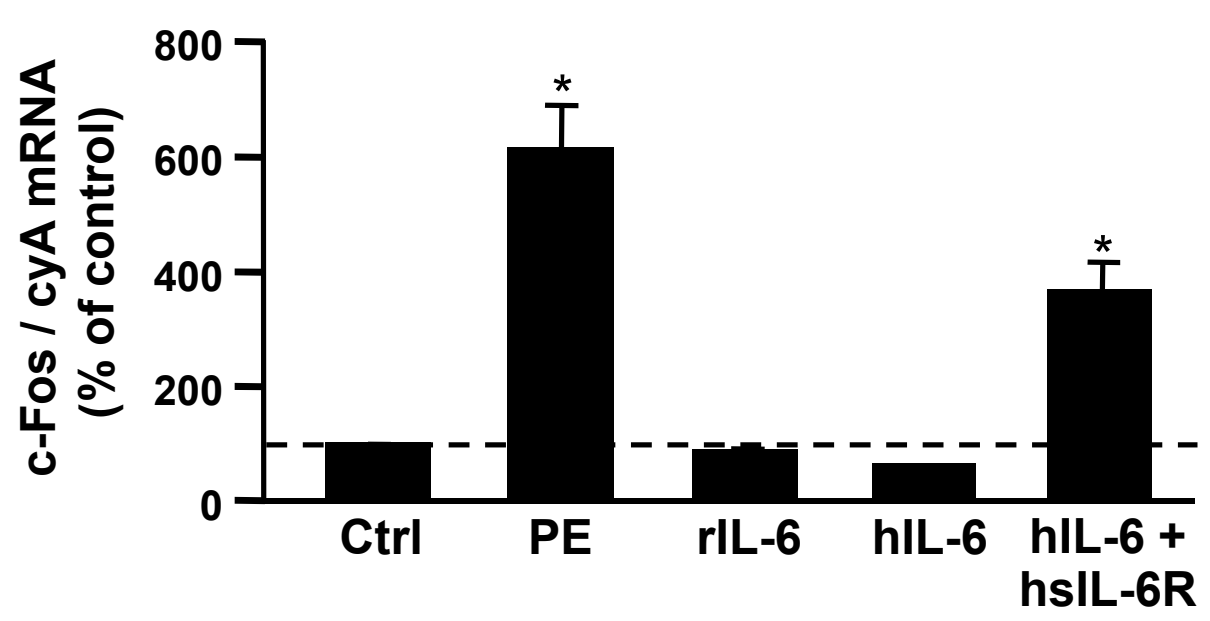

B

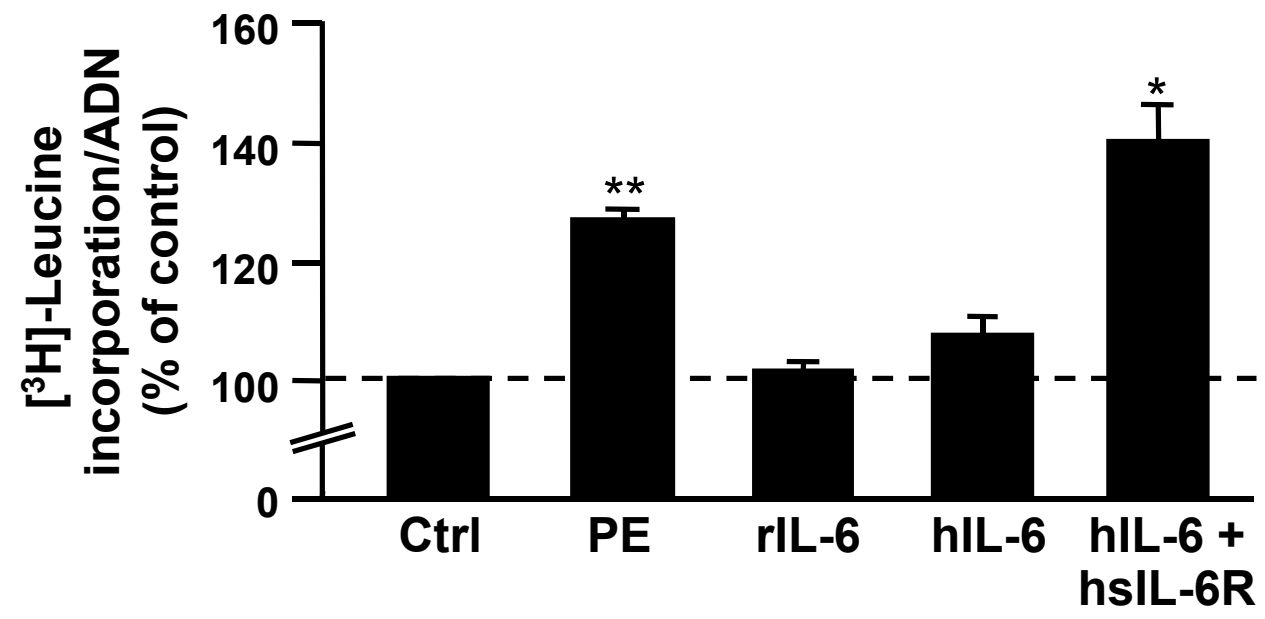

C

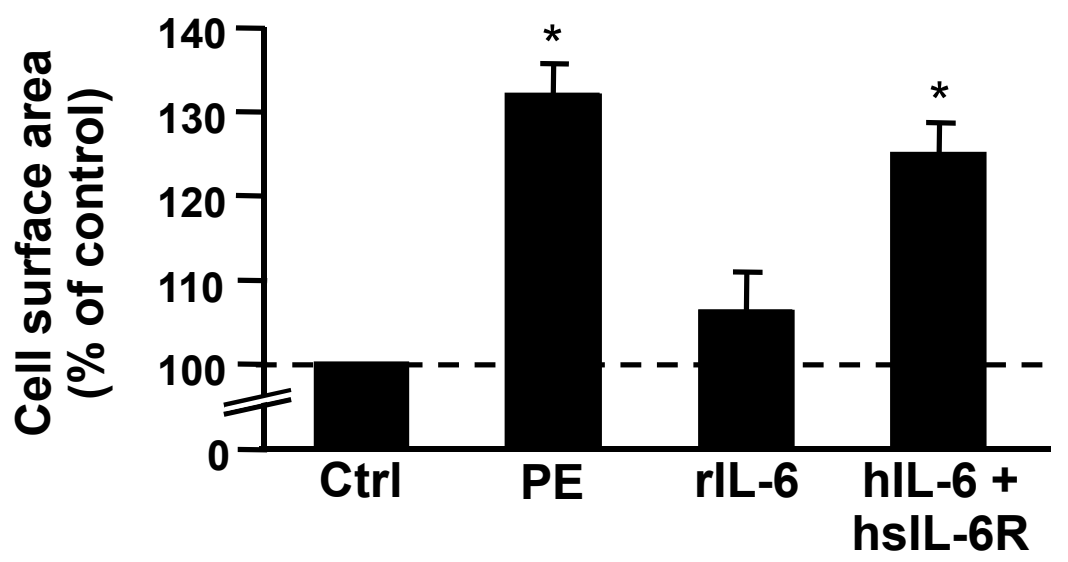

Figure 6

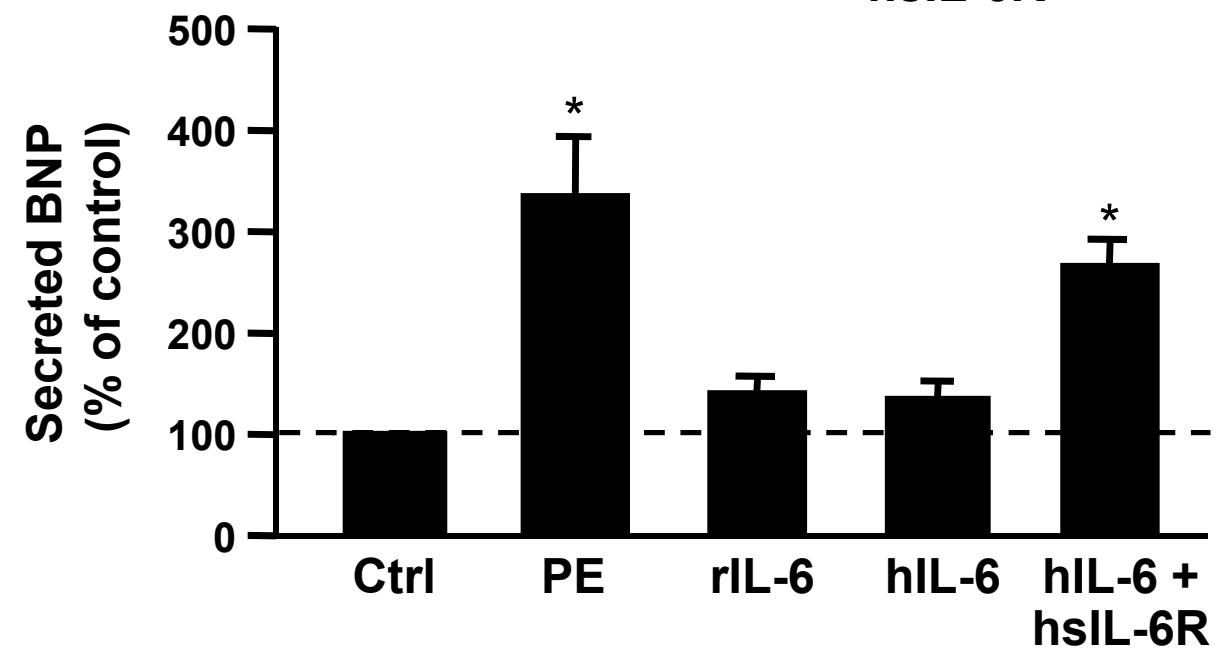




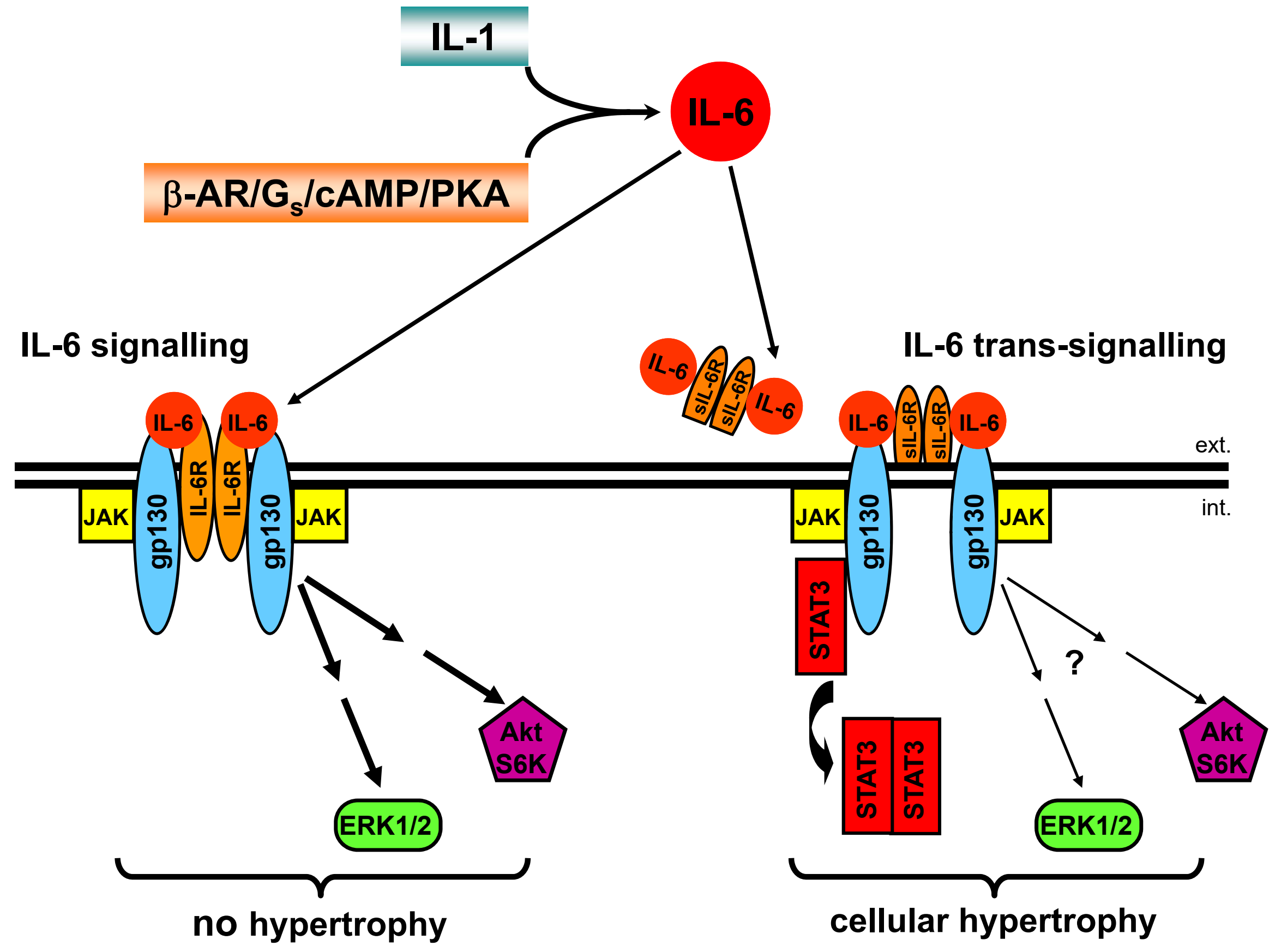

Figure 7 